
$\sum$ Research Square
Preprints are preliminary reports that have not undergone peer review.
They should not be considered conclusive, used to inform clinical practice, or referenced by the media as validated information.

\title{
Distribution Pattern of Macrobenthic Organisms In A Tropical Monsoon Influenced Port, New Mangalore, India
}

Purushothaman Atchuthan

National Institute of Oceanography CSIR

Dattesh Vithoba Desai ( $\sim$ ddattesh@nio.org)

National Institute of Oceanography CSIR https://orcid.org/0000-0001-8712-9138

Arga Chandrashekar Anil

National Institute of Oceanography CSIR

\section{Research Article}

Keywords: Macrobenthos, Polychaetes, Sediment, New Mangalore Port, Perturbations

Posted Date: July 13th, 2021

DOI: https://doi.org/10.21203/rs.3.rs-594144/v1

License: () (i) This work is licensed under a Creative Commons Attribution 4.0 International License. Read Full License 


\section{Abstract}

Study was carried out to understand the impact of natural and anthropogenic impacts on the macrobenthic organisms at the New Mangalore port, influenced by south-west monsoon located along the south-west coast of India. Soft bottom macrobenthos are the group of highly diverse benthic invertebrates in the coastal regions. The spatio-temporal variation in their abundance and diversity was observed along with the variations in the water column and sediment characteristics. Among the 61 taxa of macrobenthos reported, 41 belonged to the polychaetes. The organic carbon levels of $>2 \%$ supported higher abundance of deposit feeders. A correlation in the abundance of polychaetes and sediment characteristics along with dissolved oxygen and pore water nutrients was observed. A shift in the community of macrobenthic species in response to environmental parameters was observed with the change in the season. During post-monsoon I, Prionospio sp., was dominant, whereas during pre-monsoon the amphipod, Ampelisca sp. was dominant. The abundance of opportunistic polychaetes, Prionospio sp., Cossura sp., and Tharyx filibranchia varied with the seasons indicating a change in the habitat characteristics during different seasons. The occurrence and dominance of macrobenthic speceis was influenced by the physical processes mainly governed by the exchange of seawater between the port and the Arabian sea. The stations located in the high circulation area showed higher seasonal variation in the macrobenthic community indicating pivotal role of local hydrodynamics on macrobenthic organisms. The occurrence of opportunistic species inside the port demonstrate the role of anthropogenic stress in structuring the macrobenthic community.

\section{Highlights}

- Elucidated spatio-temporal variation in macrobenthic taxa at New Mangalore port.

- 61 taxa of macrobenthos were reported, and polychaetes dominated with 41 taxa.

- Shift in the dominance of macrobenthic species was observed with change in seasons.

- Occurrence of opportunistic species validated anthropogenic stress within the port.

- Perturbations due to local hydrodynamics in port influenced macrobenthic community.

\section{Introduction}

Soft-bottom macrobenthos is an important ecological group (Zhang et al. 2012), and play an important role in the bioturbation process and indirectly promote oxygen flux and circulation through sediment to promote bacterial activities involved in organic matter recycling, sediment decomposition, and secondary production (Lind 1979; Snelgrove 1998; Woodward and Hildrew 2002; Covich et al. 2004). Some macrobenthic organisms inhabit beneath the sediment surface where they interact with the marine environment through feeding, digging and building tubes (Zhang et al. 2012; Thilagavathi et al. 2013). They are abundant, easy to collect and highly diverse with representatives from different phyla (Snelgrove 1998), colonizing different habitats and adopt different types of foods (Rhoads 1974; Fauchald and Jumars 1979; Weisberg 1997; Little, 2000; Sarker et al. 2016). Combined with their relatively sedentary lifestyles such as long life-cycles, macrobenthos respond to environmental changes via community-related variations including species composition, diversity, abundance, and biomass (Koperski, 2010; Rakocinski et al. 1997; Weliange et al. 2017). Thus, their abundance and distribution can be used as effective ecological indicators to assess the health of the benthic habitat (Tong et al. 2013; Keeley et al. 2014; Wang et al. 2021). Coastal ecosystems are complex environments known for their importance in terms of biodiversity, however, they are also extremely sensitive as they are exposed to several anthropogenic pressures (e.g. pollution, tourism, overfishing, sediment discharge, shipping, industrial and urban developments). They host a range of benthic assemblages and are threatened by anthropogenic stressors and habitat degradation as a result of coastal developments (Parulekar,1973; Pawar and Al-Tawaha 2017). These disturbances are directly or indirectly responsible for the deterioration of marine benthic habitats (Mosbahi et al. 2019). In addition, benthic assemblages mostly respond predictably to pollution (Pearson and Rosenberg 1978; Hart and Fuller 1979) and, inhabit the stressful enivornment over several months to years (Sarker et al. 2016).

Ports, which are the sheltred water bodies are subjected to various forms of anthropogenic activities such as sewage or municipal runoff, terrestrial runoff during the monsoon, port related activities such as dredging, oil spill, petroleum effluents, accidental out-fall of variety of cargo handled at the port etc. Studies carried out in the some of the major ports of India indicated that the the water inside the port is eutrophicated and has high chlorophyll biomass owing to low flushing rate with the outside seawater (Sawant et al. 2007; Rajaneesh et al. 2015). Occurrence of pollutants in the harbor due to various anthropogenic, industrial, and maritime discharges renders the harbor environment hostile for native species and opens a window for the proliferation of opportunistic native and exotic species (Galil 2000). As harbor areas have empty niches, they are prone to marine bio-invasion especially due to ballast water discharge from the ships (Rilov and Crooks 2009; Mandal and Harakantra 2013). There are no reports on the distribution and abundance of macrobenthos from the New Mangalore Port, however, few studies have reported their distribution and abundance off the Mangalore coast (Devassy et al. 1987; Gopalakrishnan and Nair 1998; Joydas 2002; Kumar et al. 2004; Musale and Desai 2011).

The present study was carried out to observe the distribution of macrobenthic community at the New Mangalore Port. The results will provide inputs in elucidating the distribution and occurrence of macrobenthic speceis in a disturbed environment such as the ports from a tropical monsoon influenced environment and such ecosystems in other parts of the world. Based on the physical characteristics mainly the circulation within the port and the port related activites, the area within the port was divided as low circulation area (LCA), high circulation area (HCA) and oil and fertilizer wharf (OFW) to (1) observe spatial and temporal variation in the environmental variables and the sediment chanractersits (2) to evaluate the variation in macrobenthic speceis diversity over a spatial and temporal scale, and (3) to elucidate the relationship between macrobenthic community and environmental variables and sediment charactrisitcs.

\section{Materials And Methods}


The New Mangalore Port is a modern all-weather (operative during all the seasons) port and is the largest liquefied petroleum gas handling port in the country. The total cargo handling capacity of the port is 38 million tones with 15 berths. The major imports of the port include Crude Oil and Petroleum, Oils, Lubricants, liquefied petroleum gas, wood pulp, timber logs, finished fertilizers, liquid ammonium, phosphoric acid, other liquid chemicals, containerized cargo, etc (Naik and Kunte 2016).

In the present study, 19 stations were selected for the collection of samples (Fig. 1). The port area has been divided into three areas depending upon the portrelated activities at different berths, and the hydrographic conditions such as tides and currents which govern the exchange of seawater with the Arabian sea. They were (1) Low Circulation Area (LCA) which is comparatively a semienclosed area (stations 1-8) (2) Oil and Fertilizer Wharf (OFW) which handles the liquid cargo mainly oil and fertilizers (stations 10-14), (3) High Circulation Area (HCA) stations 9 and 15-19 which are located in the main channel connecting the port (Fig. 1). The New Mangalore is situated on the south-west coast of India, and, is influenced by the south-west monsoon and about $90 \%$ of the rainfall is received during the months of May to October, however, the active monsoon months are from June to September, with very low rainfall during May and October. Depending upon this the year is divided into monsoon (June to September), post-monsoon (October to January), and pre-monsoon (February to May). With the change in the season, the direction of currents also change. During the southwest monsoon, due to the heavy rains, it has been observed that reversal of currents in the approach channel, which is the only opening for the ships to enter port area. During the northeast monsoon (November to February) the currents are towards North. The New Mangalore Port has a water spread area of $\sim 1.29 \mathrm{sq}$. km. There are two break waters, the northern and southern breakwater which make up the approach channel which is about $245 \mathrm{~m}$ wide. Near the edge of the breakwaters a strong drift has been reported, which is variable and in the approach channel it can be as high as 1.5 knots during the southwest monsoon (Port Risk Assessment Report 2011). Analysis of data collected in and around Mangalore revealed that $0.4 \%$ of the waves have a height of $4.9 \mathrm{~m}$, and the wave height during the non-monsoon months is comparatively low (more than $1.5 \mathrm{~m}$ ) (Ramteke et al. 2015). The sampling was carried out during the month of November 2011 (Post-monsoon abbreviated as PM I), May 2012 (Pre-monsoon - PreM), September 2012 (Monsoon - MON) and December 2012 (Post monsoon - PM II) representing different seasons.

The surface and near-bottom seawater samples were collected in triplicate using a Niskin water sampler for measuring salinity and dissolved oxygen (DO) as described by Parsons et al. (1984). Nutrients from seawater (nitrite, nitrate, phosphate, and silicate) were analysed by auto-analyser (SKALAR SANplus ANALYZER). Temperature and water column depth were measured by a multiparameter Sonde DS5X (Hydrolab). The near bottom seawater samples were collected for chlorophyll-a and analysed spectrofluorometrically (Turner Trilogy; Parsons et al. 1984). The sediment samples were collected in triplicate using a Van Veen grab (sampling area of $0.04 \mathrm{~m}^{2}$ ) from an average depth of $12 \mathrm{~m}$. Sediment samples were sieved using a $500 \mu \mathrm{m}$ mesh sieve, initially preserved in $10 \%$ buffered formaldehyde in seawater containing rose bengal stain, and later transferred to $5 \%$ formalin. Sediment samples were also collected for the analysis of sediment texture, organic carbon, chlorophyll-a, and pore water nutrients. Organic carbon (OC) and sediment texture (percentage of sand, silt, and clay) were determined by standard titration method and pipette analysis method respectively (Buchanan 1984; Wakeel-el and Riley 1956). Organic carbon is expressed as percentage of sediment dry weight. Estimation of sediment chlorophyll-a was carried out using spectrophotometric analysis (Carrere et al. 2004). Macrobenthos biomass was measured as wet weight and expressed as mg. $\mathrm{m}^{-2}$ following methods by Mason et al. (1984).

Identification of macrobenthos

The macrobenthic taxa were identified microscopically (Olympus BX53) up to genus, species or family level. The Marine Species Identification Portal (http://species-identification.org) and taxonomic keys of Day (1967); Fauchald (1977); Light 1978 for polychaetes, Mookherjee (1985) for molluscs, Lincoln (1979); Barnard (1935); Rabindranath (1972) for crustaceans were used. Scientific names and identification of other macrobenthic taxa were supported by World Register of Marine Species (WoRMs) website (http://www.marinespecies.org).

Data analyses

The data on the abundance of macrobenthos were transformed to $\log (x+1)$ before carrying out the statistical analysis. The univariate measures of macrobenthic diversity (Shannon-Wiener diversity index $(H)$, Margalef's species richness index $(d)$, and Pielou's evenness index $(J)$ ) were calculated for every station (Clarke and Gorley 2001). Bray-Curtis similarity for diversity of macrobenthos was determined using PRIMER-v5 (Clarke and Gorley 2006). The percentage distribution of different sediment types obtained for each station was plotted in a ternary diagram (Shephard 1954). The stations were clustered depending upon the abundance of macrobenthic species in different regions within the port. In order to evaluate the relationships between environmental variables and macrobenthic speceis, canonical correspondence analysis (CCA) using CANOCO (version 4.5) was performed (ter Braak 1986; ter Braak and Smilauer 2002). For CCA analysis environmental data was transformed to Square-root and the species abundance were calculated using log ( $x+1)$. CCA axes 1 and 2 were framed by 0.1 and -0.1 in order to show equal distance of the length of the arrow. Seasonal variation in the total macrobenthic community is presented using SURFER-6 (developed by Golden Software Inc., USA). The data on the abundance of macrobenthos, environmental parameters and the sediment parameters were tested for normality test using Kolmogorov-Smirnov test and homogeneity (Levene test) before performing the ANOVA. Two-way ANOVA was performed to evaluate the variation in the abundance and biomass of macrobenthic organisms, chlorophyll-a, organic carbon, sand, silt, and clay as the dependent variables with respect to stations and seasons which are the considered as independent variables. In addition, factors detected to be significant by ANOVA were further analysed by Tukey HSD test. The log-transformed data was used for the analysis of variance.

\section{Results}

Hydrological parameters

The seawater temperature at the surface and near-bottom ranged from 29.2 to 29.9 (avg. $29.6 \pm 0.2$ ) ${ }^{\circ} \mathrm{C}$ and 29.2 to 29.6 (avg. $29.5 \pm 0.1$ ) ${ }^{\circ} \mathrm{C}, 28.9$ to 30 (avg. $29.5 \pm 0.3$ ) ${ }^{\circ} \mathrm{C}$ and 27.6 to 28.4 (avg. $28 \pm 0.3$ ) ${ }^{\circ} \mathrm{C}, 25.4$ to 26.9 (avg. $26.1 \pm 0.5$ ) ${ }^{\circ} \mathrm{C}$ and 24.8 to 25.4 (avg. $25.1 \pm 0.2$ ) ${ }^{\circ} \mathrm{C}, 29.0$ to 29.6 (avg. $29.2 \pm 0.2$ ) ${ }^{\circ} \mathrm{C}$ and 
28.8 to 29.3 (avg. $29.1 \pm 0.1$ ) ${ }^{\circ} \mathrm{C}$ during PM I, PreM, MON and PM II respectively (Table I). The difference in the average surface seawater temperature was 3.5 ${ }^{\circ} \mathrm{C}$ and at the bottom it was $4.4^{\circ} \mathrm{C}$ during different seasons. The seawater salinity at surface ranged between $34.4 \pm 0.3$ and $35.9 \pm 0.1$ and at near-bottom it ranged between $34.7 \pm 0.2$ and $36 \pm 0.4$ and it varied with the seasons (Table I). The dissolved oxygen concentration varied with the seasons and between surface and bottom water (Table I). The concentration of DO in bottom water was low during all the seasons, and such a trend was more prominent during the monsoon season (average DO was $1.1 \pm 1.2 \mathrm{mg} . \mathrm{L}^{-1}$ ), indicating hypoxic conditions at most of the stations. During PM II, at OFW stations, the DO concentration of the near-bottom seawater was higher than the surface seawater (Table I).

\section{Sediment texture}

The sediment texture was dominated by sand followed by clay and silt (Fig. 2) and their composition varied with the seasons. A comparison between the PM I (2011) and PM II (2012) indicated that PM I had higher percentage of sand when compared to PM II (Fig. 2A-D) indicating an inter-annual variation in the sediment texture. Different areas within the port showed variation in the sediment texture with the seasons, as stations 14 and 17 , had lower percentage of sand (47 and 62\% respectively) during PM I, and during PM II the percentage of sand was 92 and $83 \%$ respectively at these stations. In PreM, stations 3, 9, and 18 were dominated by sand (nearly $80 \%$ ), however, at other stations the sediment was dominated by clay and silt. During MON, the percentage of sand was nearly $45 \%$ followed by clay and silt (Fig. 2A-D). Sediment texture significantly varied between the stations and seasons (Two-way ANOVA; $P<0.001)$ (Table II).

The ternary diagram depicted ten classes of mixed sediment: clay, silty-clay, clayey-silt, silt, sandy-silt, silty-sand, sand, clayey-sand, sandy-clay, and combination of sand-silt-clay respectively (Fig. 2E). During PM I, the sediment was dominated by combination of sand-silt-clay and clayey-silt. During PreM season sand-silt-clay content was dominant along with clayey-sand, sandy-clay, sandy-silt, clayey-silt, silty-clay and silty sediment at different stations (Fig. 2E). The combination of sand-silt-clay was dominant along with silty-clay and clayey-silt during MON. During PM II, the sediment was dominated by sand-silt-clay at most of the stations and at few stations sediment was characterized by silt and sandy-silt.

Organic carbon

A significant variation in the organic carbon (OC) content ( 0.13 to $4.14 \%$ ) was observed with stations and seasons (Fig. 2A-D) (Two-way ANOVA; $P<0.001$ ) (Table II). The OC was minimum during PreM (ranged from 1.43 to 2.77\%) (Fig. 2B), and during PM I it ranged from 1.7 to $2.78 \%$ (Fig. $2 \mathrm{~A}$ ). The maximum variation in the $\mathrm{OC}$ was observed during MON (0.4 to $4.12 \%)$ and PM II (0.13 to $4.14 \%)$ (Fig. 2D).

Chlorophyll-a

A significant variation in the sediment chlorophyll-a was observed with the seasons and stations (Two-way ANOVA; $P<0.001)$ (Table II). The average chlorophyll-a of near-bottom seawater during PM I was $1.3 \pm 1 \mathrm{mg} \cdot \mathrm{m}^{-3}$ and it was lower then sediment chlorophyll- $a$ (Table I). A wide variation in the nearbottom seawater and sediment chlorophyll-a was observed with the seasons. During PreM, the average sediment chlorophyll-a was $7.7 \pm 2.5 \mathrm{mg}$. $\mathrm{m}^{-2}$, and the stations located in the vicinity of the channel showed higher chlorophyll-a in the near-bottom seawater. During monsoon the variation in the chlorophyll-a content in near-bottom seawater and sediment was maximum (Table I). The stations located in the LCA and OFW had higher chlorophyll-a content in the nearbottom seawater when compared to stations located in the HCA (Table I). During this season average sediment chlorophyll-a was $8.2 \pm 3.9$ mg. $\mathrm{m}^{-2}$, and higher concentration of chlorophyll-a was observed at stations located in HCA. During PM II, the average chlorophyll-a of near-bottom seawater was $8.2 \pm 3.9$ $\mathrm{mg} \cdot \mathrm{m}^{-3}$ and in the sediment the chlorophyll-a was $7.3 \pm 2.7 \mathrm{mg} \cdot \mathrm{m}^{-2}$ (Table I).

\section{Nutrients}

Seasonal variation in the nutrient concentration in near-bottom seawater and sediment pore water was observed (Supplementary Fig. 1). During PM I, the concentration of ammonium and silicate from the sediment (pore water) showed large variation with respect to the stations. However, during other seasons the nutrient concentrations did not show variation in both near-botttom seawater and sediment (pore water), except ammonium.

Macrobenthic community

A total of 61 macrobenthos taxa belonging to 8 phyla were recorded during the study. The number of taxa were 9, 32, 21 and 47 during PM I, PreM, MON, and PM II respectively. The abundance of macrobenthic organisms varied significantly between the stations and seasons (Fig. 3; Spplementray Table I). The abundance was 1063 no. $\mathrm{m}^{-2}$, 9440 no.m $\mathrm{m}^{-2}, 3835$ no. $\mathrm{m}^{-2}$, and 16139 no. $\mathrm{m}^{-2}$ during PM I, PreM, MON and PM II respectively (Fig. 3A-D; Supplementary Table I). The biomass of macrobenthic organisms also varied significantly with the seasons (Two-way ANOVA; $P<0.001)$ (Table II). The macrobenthic taxa comprised of polychaetes, crustaceans, molluscs, oligochaetes, sipunculans and nemerteans. Polychaetes were the most abundant organism's contributing to the total abundance during PM I, MON and PM II, however, during PreM season the amphipod, Ampelisca sp. was abundant (Supplementary Table I). A significant variation in the abundance of polychaetes was observed between PM I (1001 no. $\mathrm{m}^{-2}$ ) and PM II (15277 no.m ${ }^{-2}$ ). At st-18 (situated in the channel) maximum abundance of macrobenthic organisms was observed during all the seasons (Fgiure 3 A-D; Supplementary Table I).

During PM I, Prionospio sp., Cossura sp. and Polydora sp. dominated and they contributed 75\% to the total macrobenthic community (Fig. 4; Supplementary Table I (A)). Macrobenthic organisms belonging to the family Cirratulidae and the Chaetognatha, Serratosagitta sp., (31 no.m ${ }^{-2}$ in both LCA and HCA areas) also contributed to the total abundance (Supplementary Table I (A)). The Prionospio sp. was dominant in HCA (34\%) and OFW (100\%), however, in LCA, Cossura sp. was dominant (48\% contribution) followed by Prionospio sp., and this points out that Prionospio sp. was distributed in all three areas of the port. Minimum abundance of macrobenthic organisms during this season was observed in the OFW area when compared to other two areas within the port (Fig. 3 ; Supplementary Table I (A)). During PreM, the amphipod, Ampelisca sp., was dominant followed by Magelona capensis, Pelecypod, and Cossura sp. 
(Supplementary Table I (B)). The abundance of Isopod and Tharyx filibranchia was comparatively high during PreM. During this season 7192 no. $\mathrm{m}^{-2}$ macrobenthic organisms were reported from the HCA area, and Ampelisca sp. contributed $62 \%$ to the total macrobenthos, whereas, in LCA (1987 no.m ${ }^{-2}$ ) and OFW (262 no. $\mathrm{m}^{-2}$ ) the to total abundancewas comparatively low (Fig. 3B; Supplementary Table I (B)). In LCA, Cossura sp. and Pelecypod were dominant, whereas, in OFW, Cossura sp. was dominant followed by Gastropod, during this season, Pelecypods were reported in all three areas of the port. In the MON season, the abundance of polychaetes was 3835 no. $\mathrm{m}^{-2} \mathrm{MON}$, and Prionospio sp. was dominant (47\%) followed by Cossura sp., Tharyx filibranchia, and Pelecypod (Supplementary Table I (C)). During this season also the abundance of macrobenthic organisms was high in the HCA (2772 no.m ${ }^{-2}$ ) and Prionospio sp. was dominant (contributed 63\%) along with Pelecypods and Magelona capensis. Whereas, the abundance was comparatively low in LCA (755 no. $\mathrm{m}^{-2}$ ) and OWF (308 no. $\mathrm{m}^{-2}$ ), and in both these areas Cossura sp. was dominant (Supplementary Table I (C)).

Overall, the maximum abundance of macrobenthic organisms (16139 no. $\mathrm{m}^{-2}$ ) was observed during PM II (Supplementary Table I (D); Fig. 3D). The polychaetes, Mediomastus capensis (6545 no. $\left.\mathrm{m}^{-2}\right)$, Magelona capensis (2264 no. $\mathrm{m}^{-2}$ ) and Tharyx filibranchia (1925 no. $\left.\mathrm{m}^{-2}\right)$ were dominant along with Prionospio pinnata and Cossura sp. (Fig. 4; Supplementary Table I (D)). The abundance of macrobenthic organisms was higher in HCA (9024 no.m ${ }^{-2}$ ) compared to LCA (6191 no. $\mathrm{m}^{-2}$ ) and OFW (924 no. $\mathrm{m}^{-2}$ ) area (Supplementary Table I (D)). Mediomastus capensis was dominant in the LCA and HCA and contributed $41 \%$ and $43 \%$ respectively to the total abundance, whereas in OFW area, Tharyx filibranchia was dominant (Supplementary Table I (D)). The macrobenthic diversity index values were maximum during PM II and PreM season (Table IIIA). The Shannon-Weiner index ( $H$ ) was also high during these seasons (4.9 and 4.5 during PM II and PreM respectively). Species diversity was maximum during PM II followed by PreM, PM I and MON (Table IIIA) indicating significant seasonal variation in the community structure of macrobenthos. The maximum number of species were encountered in HCA during PreM and PM II season (Table IIIB).

Relationship between environmental variables and macrobenthic community

Cluster analysis indicated stations clustering in different groups based on the abundance of macrobenthic organisms (Fig. 5A-D), and the CCA analysis indicated the correlation between the abundance of macrobenthos speceis and physico-chemical variables and sediment characteristics in different regions of the port during different seasons (Fig. 5E-H). The CCA axes 1 and 2 (Eigenvalues 1 and 0.799 during PM I; 1 and 0.707 during PreM; 1 and 1 during MON and 1 and 0.765 during PM II respectively) explained the relationship between the macrobenthos and physico-chemical variables and sediment characteristic (Fig. 5E-H) between different areas of the port (LCA, OFW, HCA). In general, during all the seasons, Eigenvalues were greater than 0.5 indicated relatively good dispersal of species along different axes (ter Braak 1986). The CCA derived correlation between macrobenthic abundance and physico-chemical and sediment characteristics was 54.9\% during PM I, 38.6\% during PreM, 45.9\% during MON and 47.4\% during PM II (Fig. 5E-H). During PM I, stations 15, 17, and 18 (located in $\mathrm{HCA}$ ) indicated differences in the community structure between the stations (Fig. 5A). The st- 15 had relatively low DO and supported higher abundance of Nereis sp., whereas, at st-17, the higher abundance of Ancistrosyllis sp. was influenced by higher percentage of sand and moderate silt, along with PW silicate, sediment OC, salinity and temperature (Fig. 5E). At st-18 higher abundance of Cossura sp. and lower abundance of Magelona capensis was weakly correlated to DO and silt. In this season, OFW stations (st-13 and 14) formed group I, and these stations had higher abundance of Prionospio sp., and were weakly correlated with ammonium and near-bottom seawater temperature. The group II, represented by st-2 and st-8 located in LCA area (Fig. 5A) were dominated by Cossura sp., and represented by high sediment OC, while in the same areas, group III stations $(3,4,5$ and 6$)$ had higher abundance of Cossura sp., Prionospio sp., Cirratudiae, Tharyx filibranchia followed by Serratosagitta sp. In both these groups (II and III) macrobenthic abundance was correlated to the concentration of DO, temperature, PW phosphate, PW ammonium, OC and percentage of clay (Fig. 5E ).

During PreM, four clusters were observed and few stations did not group to form clusters (Fig. 5B). In the OFW, st- 14 had higher abundance of Tharyx filibranchia influenced by high percentage of sand and nutrients (PW ammonium and silicate). The st- 11 and st-12 from this area in group I (Fig. 5B) dominated by Cossura sp. followed by Gastropods (Fig. 5F). In HCA, every station had different dominant macrobenthic organism (Mediomastus capensis at st-9, Cossura sp. at st-17, and amphipod at st-18), and their abundance was correlated with the near-botttom seawater temperature, salinity, nitrate and percentage of silt (Fig. 5F). In LCA, at st-2 high clay and OC content was directly correlated with Tharyx filibranchia which was dominant at this station. Station 1 in this area had higher abundance of Pelecypods and it was correlated with silt. However, in group II, at st-3 and st-7 (Fig. 5B) Pelecypoda was dominant and the percentage of silt was high (Fig. 5F). The st-4 and st-8 (group III) dominated by Cossura sp. followed by Nemertea and Gastropods, and they were influenced by sediment texture (Fig. 5F). In group IV (st-5 and st-6) Cossura sp. and Magelona capensis were dominant which was correlated to the concentration of nutrients and near-bottom seawater temperature and salinity (Fig. 5B\&F).

During MON, at st-18 (HCA) Prionospio sp. was high in abundance followed by Pelecypoda, Magelona capensis, macrobenthos belonging to Class Insecta and their abundance was correlated to the sediment characteristics (texture and OC), PW phosphate and silicate (Fig. 5C\&G). The st-15 and st-19 (group I) in the HCA (Fig. 5B) had moderate abundance of Cossura sp. indicating none of the environmental variables or sediment charactristics influenced their abundance during MON season (Fig. 5F). In LCA, st-6 did not cluster and the higher abundance of Tharyx filibranchia at this station was correlated to OC and near-bottom seawater DO (Fig. 5C\&G), and these parameters also influencd the moderate abundance of Nemertea and Ostracoda. In group II stations (stations 2, 3, 4, 5, and 8), Cossura sp. was dominant and was supported by low percentage of silt, low near-bottom seawater salinity and higher PW ammonium at st-5 and high silt and clay content at st-2 (Fig. 5C\&G). At st-14 in OFW area, low OC and higher percentage of sand inluenced higher abundance of Prionospio sp. followed by Polydora sp. and Tharyx filibranchia. The dominance of Cossura sp. at st- 13 was favored by moderate concentration of silicate and ammonium along with near-bottom seawater temperature, salinity, and DO (Fig. 5C\&G). The high Eigen value (1) of axes 1 and 2 indicates a high degree of correspondence between the abundance of macrofauna and physico-chemical variables and sediment characteristic during MON season. During PM II, st-4, 11 and 17 did not cluster with other stations from their respective areas, however, st-4 (LCA) grouped with st-17 (HCA) to form group I (Fig. 5D). In group I, st-4 and st-17 had higher abundance of Mediomastus capensis followed by Magelona capensis which were influenced by high sand, low clay and silt and $\mathrm{OC}$ content (Fig. $5 \mathrm{H}$ ). During this season, among the non-clustered stations, at st-18 (HCA) higher abundance of Mediomastus capensis along with other macrobenthos was observed and and this was the most abundant macrobenthic species during this season. At this station higher abundance of Phyllodocidae was correlated with near-bottom 
seawater temperature and salinity. In group II, stations from LCA (stations 1, 2, 5, 6 and 8) were grouped, and Cossura sp. and Tharyx filibranchia were dominant and their dominance was correlated by higher percentage of sand and low OC (Fig. 5D\&H), and their dominance at st-1 and st-2 was correlated to low OC and sand indicating that they can survive and grow in habitats with multiple sediment characteristics.

\section{Discussion}

The macrobenthic community of the New Mangalore Port exhibited significant spatio-temporal variation in their distribution. The scenario during different seasons with respect to macrobenthic abundance, biomass and community structure along with sediment characteristics and environmental parameters is discussed in the following sections.

Scenario during Post-monsoon I (PM I)

During PM I, the total abundance of macrobenthos was lower when compared to other seasons. The polychaete, Prionospio sp. was the most abundant species, specifically at st-15 where the habitat was hypoxic $\left(0.9 \mathrm{mg} \cdot \mathrm{L}^{-1}\right)$, indicating their tolerance to low oxygen conditions. The occurrence of this species in high abundance along with few other macrobenthos in low oxygen concentration ( $\left.0.1 \mathrm{mg} \cdot \mathrm{L}^{-1}\right)$ has also been reported by Levin et al. (2009). The Prionospio $\mathrm{sp}$. is a deposit feeder and the dominance of sand during this season when compared to other seasons and this could be a reason for the higher abundance. The Cossura sp. and Polydora sp. which are also deposit feeders were dominant indicating they can primarily feed on the sediment organic carbon. Earlier studies have indicated that higher organic carbon possibly caused by depletion in oxygen cand lead to decline in the species diversity, abundance and biomass (Jorgensen 1977; Revsbech and Jorgensen 1986; Snelgrove and Butman 1994; Hyland et al. 2005; Musale and Desai 2011). The sediment organic carbon during this season was moderate and abundance of detritivores was higher which are able to feed and proliferate on moderate to high organic carbon. The detritivorous macroebnthic organaisms have an ability to survive in sediments with moderate organic carbon (Ansari et al. 2014). The higher abundance of macrobenthos was in HCA followed by LCA and OFW indicated distinct spatial distribution in different areas within the port. It can be noted that the tidal exchange of seawater between the port and the open sea was maximum in HCA, and this will result in healty bottom water condition owing to higher exchange of seawater and could be atttibuted to higher abundance and biomass of macrobenthos in this area. The deposit feeders, Prionospio sp. followed by Polydora sp. and Cossura sp. were dominant, and in HCA the percentage of clay was higher than LCA and OFW, and the average OC was $2.2 \%$ and such conditions are preferred by deposit feeding polychaetes. Musale et al. (2015) reported that in the Visakhapatnam port, Prionospio sp. was abundant in the outer harbor region which is a semi-polluted environment with moderate $\mathrm{OC}$ and high percentage of sand and these conditions were similar to that in the $\mathrm{HCA}$, indicating the preference of Prionospio sp. to sandy-silt habitat with OC ranging between 2-3\%. Prionospio sp. are capable of constructing tubes in which they hide from adverse conditions and also protect them from the predators (Moritz 2012), and such a habit can be attributed to their higher abundance in HCA. It is apparent that the distribution of this species is dependent on its ability to thrive in semi-polluted environment and it can be a good indicator of benthic habitat. In LCA the moderate abundance of macrobenthic organisms was observed with five dominant macrobenthic forms and the polychaete, Cossura sp. contributed $\sim 50 \%$ to the total abundance, however, the biomass was minimum. In this area, the sediment was dominated by silt, and had moderate organic carbon. Considering the properties of sediment dynamics, it has been suggested that high silt-clay fraction in the sediment contains more food particles (Sanders 1960; Dzulynski and Sanders 1962; Jayaraj et al. 2008; Musale et al. 2015) which are commonly comprised of decomposable organic constituents and this sustains higher benthic organisms.

Scenario during Pre-monsoon (PreM)

During PreM season, the macrobenthic abundance was dominated by the benthic amphipod, Ampelisca sp. (48\% to the total), a surface deposit feeder followed by the Pelecypods (10\%), and the abundance of Pelecypods was higher in LCA. Increase in tube building amphipods favor sedimentation of fine particles (Mills 1967) and this also stimulates the recruitment of other benthic species (Glemarec et al. 1986; Dauvin and Bellan-Santini 1990). Moreover, amphipod tubes may make it difficult for bivalve larvae to settle, recruit and burrow due to the reduced flow velocity amongst the tubes (Hunt 2005) and such a condition might have led to higher abundance of Ampelisca sp. (amphipod) during this season. The presence of fine particles as indicated by higher percentage of silt and clay would facilitate tube building in amphipods. The occurrence of bivalve beds have a significant negative influence on the hydro- and sediment dynamics (Levinton 1991; Alferink 2016). It can be noted that the Pelecypods were abundant in LCA followed by OFW and HCA. The bivalves are often found dominant in terms of biomass and/or abundance in coastal soft-sediment (Kautsky and Evans 1987; Norkko et al. 2001; Giles et al. 2006; Norkko and Shumway 2011) and they provide suitable habitats for other species (McGrorty et al. 1993). On the other hand, in LCA the sediment surface may have mats of amphipod tubes and polychaete worms (Family Cirratulidae), and this might reduce the water flow overlying the sediment and allow the Pelecypods to have stable conditions further allowing siphoning of water at the sediment-water interface. During this season the concentration of chlorophyll-a in the near bottom sweater was also high, which can serve as food for the bivalves.

The polychaete, Magelona capensis also contributed significantly to the total macrobenthic abundance during this season, and indicated its preference to silty-clay sediment and moderate OC. This species is capable of living as benthic filter feeder and deposit feeder, indicating its preference to fine sand to muddy sediments with moderate organic carbon. The amphipod, Ampelisca sp. has been termed as an opportunistic species, and reported in high abundance in hydrodynamically unstable areas of the Brazilian shelf (Santos and Pires-Vanin 2004) and behaves both as filter-feeding and deposit feeding organism (Paganelli et al. 2012). In the New Mangalore Port, HCA is physically more unstable compared to the other two areas (LCA and OFW) and at station 18 highly diverse groups of macrobenthos (polychaete and non-polychaetes) were reported during this season and also during other seasons. It is possible that at this port the east-west split restricts the tidal flow to a relatively small amount of water moving swiftly through the entrance, creating hydrodynamically unstable environment which may be suitable for Ampelisca sp. A method was developed by Grifoll et al. (2010) to assess the water degradation risk owing to port activities considering the characteristics and mature of pollutants along with the hydrography, and they suggested that regions with low replenishment are accompanied by higher water quality degradation risk. They also indicated that this is associated with tides and currents which depends on the geography and structure of the port on which the flow of water between the port and the open sea is depended which will determine the dilution of water within the port.

Page 6/21 
Barnard (1970), reported that the sediments in the channel are highly diverse and strongly affect the benthic population. A study carried out at Visakhapatnam port also reported dominance of crustaceans in the outer harbour region which is less polluted when compared to inner harbor during PreM season in the silty habitats (Musale et al. 2015). The stress-tolerant macrobenthic organism, Cossura sp. was abundant in OFW followed by gastropods and pelecypods (12\%). The Cossura sp. might have survived in this area over a long duration and might have enhanced their growth in anthropogenically disturbed area and can be termed as an indicator species. In OFW, the silt and sediment chlorophyll-a were considerably higher with low OC and such conditions favor suspension feeders (pelecypods and gastropods). In general higher abundance of suspension feeders may reduce the concentration of suspended particles which will enhance the growth of benthic algae (Wall et al. 2008), which could be useful as food for the pelecypods and gastropods. High densities of bivalves were reported in stable marine salinities but their abundance reduced considerably with lowering of salinity (Pillay and Perissinotto 2008) and this can be attributed to occurrence of pelecypods in the high saline bottom water during PreM and decrease in their abundance during monsoon.

\section{Scenario during Monsoon}

During monsoon, the abundance of macrobenthic organisms significantly varied within different areas of the port (Two-way ANOVA; P $<0.001)$. As observed in other seasons, during monsoon also higher abundance of macrobenthic organisms was reported in HCA and lower in OFW. The near-bottom seawater DO concentration indicated hypoxic concitions, and most of the organisms reported were deposit feeders which had an ability to inhabit polluted hypoxic conditions. It has been reported that the severity of hypoxia affects the benthic organisms (Diaz and Rosenberg 1995) and as the severity of hypoxia increases towards anoxia, sensitive species die-off decreasing the macrobenthic diversity of the affected area (Sturdivant 2011) which can be attributed to low abundance and diversity of macrobenthic organisms during MON. The OC was maximum during the monsoon, and this season has been characterized by collapse and sinking of phytoplankton bloom (Sivadas et al. 2013) which contribute to higher OC in the sediment. Though OC is an important food source for most of the macrobenthic organisms, higher organic carbon causes decline in species diversity, abundance, and biomass, possibly by depleting the oxygen concentration (Jørgensen 1977; Revsbech and Jørgensen 1986; Snelgrove and Butman 1994; Hyland et al. 2005). In general, all stations in the OFW had low DO concentration and this region had minimum abundance of benthic organisms during monsoon. Such a condition may not impact certain macrobenthic polychaete species such as Prionospio sp. and Cossura sp. which can surive hypoxic conditions (Levin et al. 2009) which are generally found in low numbers and are called opportunistic species. The abundance of macrobenthic orgnaims was higher in HCA contributed by Prionospio sp., pelecypod and Magelona capensis. The Prionospio sp. has been considered as an indicator of organic enrichment in subtidal areas (Elias et al. 2005), and it was dominant at stations which had high chlorophyll-a content, moderate $\mathrm{OC}$ and high silt and clay. This species has been reported off the southwest coast of India in high abundance in high OC (3\%) condtion and has been termed as indicator of organically enriched sediment (Musale and Desai 2011). In HCA, the effect of major environmental parameters was moderate and OC was also low (1.9\%) benefitting the opportunistic species (Cossura sp., Prionospio sp. Polydora sp.). Among these, Cossura sp. is a well-known opportunistic species (Sivadas et al. 2010) and also the most dominant species in OFW area.

Scenario during Post-monsoon II (PM II)

During PM II the abundance of macrobenthos was maximum and Mediomastus capensis, Tharyx filibranchia and Cossura sp. contributed nearly $60 \%$ to the total abundance, while about $50 \%$ of the sediment was silty-clay and OC was 3\% and such conditions contributed to their higher abundance. The $M$. capensis, and the species belonging to Genus Mediomastus, which subsurface deposit feeders are predominantly found in silty and clayey sediments (Stewar et al. 2002). The New Mangalore Port basin was developed on a sandy beach, however, the major portion of the channel is located on the silty bed (Dattatri et al. 1997; Parvathy et al. 2014). Even though the littoral drift from the adjacent beaches is negligible, considerable amount of siltation occurs in the approach channel and port basin during southwest monsoon season as a result of deposition of suspended sediment due to coastal and tidal currents, and nearly $80 \%$ siltation has been observed during monsoon when the wave activity is at its maximum (Parvathy et al. 2014). This structural pattern is ideal for most of the macrobenthic organisms. The Mediomastus sp. an opportunistic species capable of inhabiting turbulent environment with moderate organic carbon. In this season, Mediomastus capensis was dominant at st-18 (station located at the port mouth) which has been considered as a disturbing location owing to its location in the HCA and the average OC was low (1.9\%). Rivero et al. (2005) reported that, the mouth of the Mar del Plata Harbor (Argentina) is characterized by high environmental energy and Mediomastus sp. was dominant and these species can flourish in habitat with moderate amount of OC (Pearson and Rosenberg 1978). Basically, some surface deposit feeders (Tharyx filibranchia) and sub-surface deposit feeder (Mediomastus sp.) are not capable of thriving in low oxygen conditions, however they appeared to be tolerating stressful conditions (low DO concentrations) during MON. The abundance of Mediomastus capensis and Tharyx filibranchia during PM II indicate the return of normoxic conditions in the benthic environment at this port, which indicates to the seasonal variation in the macrobenthic community. The dominant species were Mediomastus capensis, Tharyx filibranchia and Cossura sp., which are deposit feeders capable of feeding on freshly settled organic carbon and the subsurface deposit feeders (SSDF) capable of feeding on aged organic matter in the sediment.

The maximum abundance in HCA was contributed by Mediomastus capensis, Magelona capensis and Sternaspis scutata, which are subsurface deposit feeders and burrowers and their feeding activity usually occurs below the surface (Jumars et al. 2015). Surface deposit feeders and burrowers are commonly observed in high abundance when the sediment has fine grains and high organic matter (Mendez 2013) as observed in HCA. The low OC in HCA compared to LCA can be attributed to its utilization by the deposit feeders. Souza et al. (2013), emphasized that Magelonids are mainly non-selective surface deposit feeders, but some species exhibit alternate feeding mode (suspension feeding) (Fauchald and Jumars 1979), and such alteration in feeding strategies may support Magelonids to inhabit both muddy and sandy sediments (Rouse and Pleijel 2001).

It was observed that at oil berth (station 10) in OFW, the macrobenthic organisms were not reported or absent during all the seasons except during PM II. It has been reported that in Bahrain where the industrial growth focuses on the segment of oil refining, aluminum and petrochemical industries they generate effluents which contain hydrocarbons (Sridhar 2015), and these effluents can cause the issues of macrobenthic groupings which involve altering the community structure, greater numbers of species, and decrease in the normal biodiversity. This can be attributed to lower abundance of opportunistic polychaetes in OFW compared to LCA and HCA. 
As discussed in the previous sections, the community composition and abundance of macrobenthos varied with the seasons, and indicated a shift in the community structure and also the dominance of macrobenthic species within the port area. Such a shift in the community can be attributed to the significant variations in the sediment characteristics mainly the texture, organic carbon and the sedeiment chlorophyll-a. The higher bottom water column chlorophyll-a will contribute to higher chlorophyll-a in the surficial sediments. Jenness and Duineveld (1985) indicated that tidal currents strongly affect the distribution of the algae (phytoplankton) at the sediment-water interface, including other suspended organic material and detritus which also follows similar pattern, and the algae are deposited on the sediment surface during periods of slack tidal currents, providing food source for epibenthic fauna and other surface deposit feeders. They also pointed out that this high level of chlorophyll-a was alternatively buried in the sediment to a depth of $5 \mathrm{cms}$ and then resuspended. The port construction also determines the current pattern which influences the water stagnation and flushing in the regions of breakwater or landfills (Grancharova and Grancharov 2013). If waste water is flown into the region where the circulation or flushing is low in the port, it can deteriorate the habitat owing to increase in phytoplankton as a resultant of eutrophication (Champ 2003). This points out the importance of water column chlorophyll-a in structuring benthic diversity and community structure. Higher bottom water chlorophyll-a during PreM supported higher abundance of suspension feeders and also surface deposit feeders, and similar pattern was also observed during MON season. Several studies have indicated poor water quality due to anthropogenic activities in major ports of India and attributed this to the weak flushing (Sawant et al. 2007; Musale et al. 2015; Rajaneesh et al. 2015). The HCA area, which has been considered as hydrodynamically active had maximum abundance of macrobenthic organisms during PreM and MON season contributed by deposit feeders and suspension feeders. During PM II, maximum abundance of macrobenthos was observed specifically in the HCA followed by LCA. During this season the sediment chlorophyll-a was maximum in the HCA followed by LCA and similar trend was also observed for the near-bottom seawater chlorophyll-a and all the dominant organisms reported were deposit feeders. Thus it can be stated that the influx of food from the water column into the sediment may be sustaining the higher abundance of benthic epifauna. The CCA also showed correlation between the abundance of macrobenthic speceis and environmental variables

and sediment texture, suggesting optimum or favorable conditions for the macrobenthic organisms to survive and proliferate during PM II. The low percentage of organic carbon can be attributed to its utilization by deposit feeders in this area owing to their higher abundance.

\section{Conclusion}

This is the first report on the distribution of macrobenthic organismsin the New Mangalore Port, a tropical monsoon-influenced environment. Seasonal variation in the abundance and biomass of macrobenthic organisms was observed, and it varied with different areas within the port owing to the variation in the sediment characteristics, environmental variables and perturbations in the region. The variation in the hydrodynamics conditions with the seasons had significant impact on the occurrence and distribution of macrobenthic organisms. The occurrence of pollution indicator species such as Prionospio sp., Cossura sp. and Tharyx filibranchia in the port area pointed that the area is anthropogenically disturbed. The dominance of amphipod, Ampelisca sp. in the channel connecting port to the open sea can be attributed to its dual mode of feeding and preference to hydrodynamically unstable conditions. The baseline information on the benthic biodiversity generated in this study will be helpful for future research and to compare the potential impact at the port environment.

\section{Declarations}

\section{Acknowledgment}

We thank the Director, CSIR-National Institute of Oceanography, Goa for support and encouragement. This work was carried out as a part of the Ballast Water Management Programme, India, funded by the Directorate General of Shipping, Government of India. This is a NIO contribution \#\#\#\#.

Funding: This study was funded by the Directorate General of Shipping, Government of India, and award no. GAP2429.

\section{Authors Contribution:}

AP: Formal analysis, Investigation, Methodology

DD: Conceptualization, Data curation, Supervision, Resources, Writing - review \& editing

ACA: Conceptualization, Funding acquisition, Project administration, Review \& editing

Conflict of Interest: The authors declare that they have no conflict of interest.

Consent to Participate: Not applicable

Consent to Publish: Not applicable

Ethical approval: No animal testing was performed during this study.

Data Availability: All data generated or analysed during this study are included in this manuscript and data is also provided as supplementary data file.

\section{References}

1. Alferink N (2016) Modeling the influence of mussels and oysters on hydrodynamics and sediment transport. Master thesis. University of Twente, Netherlands. 
2. Anil AC, Venkat K, Sawant SS, Dileepkumar M, Dhargalkar VK, Ramaiah N, Harkantra SN, Ansari ZA (2002) Marine bioinvasion: Concern for ecology and shipping. Curr Sci 83:214-218.

3. Ansari KGMT, Manokaran S, Raja S, Lyla PS, Khan SA (2014) Interaction of free-living marine nematodes in the artificial mangrove environment (southeast coast of India). Environ Monit Assess 186:293-305

4. Barnard KH (1935) Scientific Results of the Vernay-Lang Kalahari Expedition, March to September 1930, Crustacea. Annls Transv Mus 16:481-492.

5. Barnard JL (1970) Sublittoral Gammaridea (Amphipoda) of the Hawaiian Islands. Smithson Contrib Zool 34:1 -286.

6. Buchanan JB (1984) Sediment analysis. In: Holme NA, McIntyre AD (eds) Methods for the Study of Marine Benthos. Blackwell Scientific Publications, Oxford and Edinburgh, pp 41-645.

7. Carrere V, Spilmont N, Davoult D (2004) Comparison of simple techniques for estimating chlorophyll a concentration in the intertidal zone using high spectral resolution field-spectrometer data. Mar Ecol Prog Ser 74:31-40.

8. Champ MA (2003) Economic and environmental impacts on ports and harbors from the convention to ban harmful marine anti-fouling systems. Mar Poll Bull 46:935- 940 .

9. Clarke KR (1993) Non-parametric multivariate analyses of changes in community structure. Austr J Ecol 18:117-43.

10. Clarke KR, Gorley RN (2001) In: Clarke KR, Gorley RN (eds) PRIMER v5, User Manual/Tutorial. PRIMER-E Limited, Plymouth, pp 91.

11. Clarke KR, Gorley RN (2006) PRIMER v6: User manual/tutorial. PRIMER-E, Plymouth.

12. Covich AP, Austen MC, Barlocher F, Chauvet E, Cardinale BJ, Biles CL, Inchausti P, Dangles O, Solan M, Gessner MO, Statzner B, Moss BR (2004) The role of biodiversity in the functioning of freshwater and marine benthic ecosystems. BioScience 54:767-775.

13. Darbra RM, Ronza A, Stojanovic TA, Wooldridge C, Casal J (2005) A procedure for identifying significant environmental aspects in sea ports. Mar Pollut Bull 50:866-874.

14. Dattatri J, Kamath MM (1997) Littoral drift and maintenance dredging at New Mangalore Port. Second Indian National Conference on Harbour and Ocean Engineering, 1:578-585.

15. Dauvin JC, Bellan-Santini D (1990) An overview of the amphipod genus Haploops (Ampeliscidae). J Mar Biol Assoc UK 70:887-903.

16. Day JH (1967) A monograph on the polychaeta of Southern Africa. Br Mus Nat Hist 656:30-878.

17. Devassy VP, Achuthankutty CT, Harkantra SN, Sreekumaran Nair SR (1987) Effect of industrial effluents on biota: A case study off Mangalore, west coast of India. Indian J Mar Sci 16:146-150.

18. Diaz R, Rosenberg R (1995) Marine benthic hypoxia: a review of its ecological effects and the behavioural responses of benthic macrofauna. Oceanogr Mar Biol Annu Rev 33:245.

19. Dolbeth M, Teixeira H, Marques JC, Pardal MA (2009) Feeding guild composition of a macrobenthic subtidal community along a depth gradient. Scien Mar 73:225-237.

20. Dzulynski S, Sanders JE (1962) Current marks on firm mud bottoms. Trans Conn Acad Arts Sci 42:57-96.

21. Elias R, Palacios JR, Rivero MS, Vallarino EA (2005) Short-term responses to sewage discharge and storms of sub tidal sand-bottom macrozoobenthic assemblages off Mar del Plata City, Argentina (SW Atlantic). J Sea Res 53:231-242.

22. Fauchald K (1977) The polychaete worms: Definitions and keys to the orders, families and genera. Natural History Museum of Los Angeles County Science Series. 28:1-190.

23. Fauchald K, Jumars PA (1979) The diet of worms: a study of polychaete feeding guilds. Oceanogr. Mar Biol Annu Rev 17:193-284.

24. Galil BS (2000) A sea under siege-alien species in the Mediterranean. Biol Invasion. 2:177-186.

25. Gardiner JS (1903) In: Gardiner JS (ed) The Fauna and Geography of the Maldive and Laccadive Archipelagoes. Cambridge University Press, Cambridge, pp 314-346.

26. Giles H, Pilditch CA, Bell DG (2006) Sedimentation from mussel (Perna canaliculus) culture in the Firth of Thames, New Zealand: impacts on sediment oxygen and nutrient fluxes. Aquaculture 261:125-140.

27. Glemarec M (1986) Ecological impact of an oil-spill: utilisation of biological indicators. IAWPRC-NERC Conference, July 1985. IAWPRC J 18:203-211.

28. Gopalakrishnan TC, Nair KKC (1998) Subtidal benthic macrofauna of the Mangalaore coast, West coast of India. Ind J Mar Sci 27:351-355.

29. Grancharova V, Grancharov I (2013) Sustainable port development in connection with environmental regulations. J Mar Technol Environ 2:19-24.

30. Gray JS (1981) In: Gray JS (ed) An Introduction to the Structure and Function of Marine Sediments. Cambridge Studies in Modern Biology 2, Cambridge University Press, Cambridge, pp 185.

31. Grifoll M, Jordà G, Borja Á, Espino M (2010) A new risk assessment method for water quality degradation in harbour domains, using hydrodynamic models. Mar Poll Bull 60:69-78.

32. Hart CW, Fuller SLH (1979) In: Hart CW, Fuller SLH (eds) Pollution Ecology of Estuarine Invertebrates. Academic Press, New York, pp 406.

33. Hunt HL (2005) Effects of sediment source and flow regime on clam and sediment transport. Mar Ecol Progr Ser 296:143-153.

34. Hyland J, Balthis L, Karakassis I, Magni P, Petrov A, Shine J, Vestergaard O, Warwick R (2005) Organic carbon content of sediments as an indicator of stress in the marine benthos. Mar Ecol Progr Ser 295:91-103.

35. Ingole BS, Ansari ZA, Parulekar AH (1998) Spatial variation in meiofaunal abundance of some coralline beaches of Mauritius. J Trop Ecol 39:103-108.

36. Jayaraj KA, Sheeba P, Raichandran C, Arun PK, Praseeda KS, Nisha PA, Rasheed KA (2008) Response of infaunalmacrobenthos to the sediment granulometry in a tropical continental margin-southwest coast of India. Estuar Coast Shelf Sci 77:743-754.

Page $9 / 21$ 
37. Jenness MI, Duineveld GCA (1985) Effects of tidal currents on chlorophyll-a content of sandy sediments in the southern North Sea. Mar Ecol Prog Ser 21:283-287.

38. Jongman RHG, Ter Braak CJF, Van Tongeren OFM (1995) Data Analysis in Community and Landscape Ecology. Cambridge University Press, Cambridge. 39. Jørgensen BB (1977) The sulfur cycle of a coastal marine sediment (Limfjorden, Denmark). Limnol Oceanogr $22814-832$.

40. Joydas TV (2002) Macrobenthos of the shelf waters of the west coast of India. Ph.D. Thesis, Cochin University of Science and Technology.

41. Jumars PA, Dorgan KM, Lindsay SM (2015) Diet of Worms Emended: An Update of Polychaete Feeding Guilds. Annu Rev Mar Sci 7:497-520.

42. Kautsky N, Evans S (1987) Role of biodeposition by Mytilusedulis in the circulation of matter and nutrients in a Baltic coastal ecosystem. Mar Ecol Prog Ser 38:201-212.

43. Keeley NB, Macleod CK, Hopkins GA, Forrest BM (2014) Spatial and temporal dynamics in macrobenthos during recovery from salmon farm induced organic enrichment: When is recovery complete?. Mar Poll Bull 80(1-2):250-262.

44. Kennedy WJ (1978) Nutrient inactivation with aluminum sulfate as a lake reclamation technique. Ph. D. Dissertation, Kent State University, Kent, OH.

45. Kensler CB (1964) The crevice habitat in western Norway. Sarsia 17:21-32.

46. Koperski P (2010) Diversity of macrobenthos in lowland streams: ecological determinants and taxonomic specificity. J Limnol 69:1-14.

47. Kumar BM, Katti RJ, Moorthy KSV, D’Souza RK (2004) Macrobenthos in relation to sediment characteristics of nearshore waters of Chitrapur, West coast of India receiving industrial effluents. Asian Fish Sci 17:21-28.

48. Levin LA, Ekau W, Gooday AJ, Jorissen F, Middelburg JJ, Naqvi SWA, Neira C, Rabalais NN, Zhang J (2009) Effects of natural and human-induced hypoxia on coastal benthos, Biogeosciences 6:2063-2098.

49. Levinton JS (1991) Variable feeding behavior in three species of Macoma (Bivalvia: Tellinacea) as a response to water flow and sediment transport. Mar Biol 110:375-3.

50. Light WJ (1978) In: Lee W (ed), Spionidae (polychaeta Annelida), Invertebrates of the San Francisco Bay estuary ecosystem. Boxwood Press, Pacific Grove, California, pp 211.

51. Lincoln RJ (1979) In: Lincoln RJ (ed) British Marine Amphipoda: Gammaridea. British Museum of Natural History, i-iv, pp 658.

52. Lind OT (1979) In: Lind OT (ed) Handbook of common method in limnology (2 ${ }^{\text {nd }}$ edn). The C.V. Mosby Company, St. Louis, pp $136-145$.

53. Little C (2000) In: Little C (eds) The Biology of Soft Shores and Estuaries. Oxford University Press, New York, pp 158.

54. Mandal S, Harkantra SN (2013) Changes in the softbottommacrobenthic diversity and community structure from the ports of Mumbai, India. Environ Monit Assess 185:653-672.

55. Mason WT, Lewis PA, Weber Cl (1985) An evaluation of benthic macroinvertebrate biomass methodology - Part 2 field assessment and data evaluation. Environ Monit Assess 5(4):399-422.

56. McGrorty S, Goss-Custard JD, Clarke RT (1993) Mussel Mytilusedulis(Mytiliacea) dynamics in relation to environmental gradients and intra-specific interactions. Neth J Aquat Ecol 27:163-171.

57. Mendez N (2013) Trophic categories of soft-bottom epibenthic deep-sea polychaetes from the southeastern Gulf of California (Mexico) in relation with environmental variables. Pan-Am J of Aqu Sci 8(4):299-311.

58. Mills EL (1967) The biology of an ampeliscid amphipod crustacean sibling species pair. J Fish Res Board Can 24:305-355.

59. Mookherjee HP (1985) In: Mookherjee HP (ed). Contributions to the Molluscan fauna of India, Part III. Marine molluscs of the Coromandel Coast, Palk Bay and gulf of Mannar Gastropoda:Mesogastropoda,(Part - 2); Zoological Survey of India, Kolkata, pp 129.

60. Moritz D (2012) Composition and distribution of the macrozoobenthic communities on the shelf off Angola. Master Thesis Marine Biology, University of Rostock, Germany.

61. Mosbahi Serbaji MM, Pezy JP, Neifar L, Dauvin JC (2019) Response of benthic macrofauna to multiple anthropogenic pressures in the shallow coastal zone south of Sfax (Tunisia, Central Mediterranean Sea). Environ Pollut 253:474-487.

62. Muniz P, Pires AMS (1999) Trophic structure of the polychaetes in the São Sebastião Channel (southeastern Brazil). Mar Biol 134:517-52.

63. Musale AS, Desai DV (2011) Distribution and abundance of macrobenthicpolychaetes along the South Indian coast. Environ Monit Assess 178:423-436.

64. Musale AS, Desai DV, Sawant SS, Venkat K, Anil AC (2015) Distribution and abundance of benthic macroorganisms in and around Visakhapatnam Harbour on the east coast of India. J Mar Biol Assoc UK 95:215-231.

65. Naik D, Kunte P (2016) Impact of Port Structures on the Shoreline of Karnataka, West Coast, India. IJARSG 5: $1726-1746$.

66. New Mangalore Port Trust Risk Assessment for Collision, Grounding and Oil Pollution 2012. (newmangaloreport.gov.in).

67. Norkko J, Shumway SE (2011) In: Shumway SE (ed) Bivalves as bioturbators and bioirrigators, Shellfish aquaculture and the environment. WileyBlackwell Oxford, United Kingdom, pp 297-317.

68. Norkko A, Hewitt JE, Thrush SF, Funnell GA (2001) Benthic - pelagic coupling and suspension - feeding bivalves: linking site - specific sediment flux and biodeposition to benthic community structure. Limnol Oceanogr 46:2067-2072.

69. Noyel V, Desai DV (2020) Spatio-temporal variation in the macroebnthos of Paradip port, east coast of India. Cur Sci 119(1):68-82.

70. Paganelli D, Marchini A, Occhipiniti-Ambrogi A (2012) Functional structure of marine benthic assemblages using Biological Traits Analysis (BTA): a study along the Emilia-Romagna coastline (Italy, North-West Adriatic Sea). Estuar Coast Shelf Sci 96:245-256.

71. Parulekar AH (1973) Studies on intertidal ecology of Anjidiv Island. Abstracts of the Indian National Science Academy 39:611-631. 
72. Parvathy KG, Gopinath DI, Dwarakish GS (2014) Sediment Dynamics in New Mangalore Port- An Overview International Symposium on Integrated Water Resources Management (IWRM-2014).

73. Parsons TR, Maita Y, Lalli CM (1984) A Manual of Chemical and Biological Methods for Seawater Analysis. Pergamon Press, Oxford, pp 173.

74. Pawar PR, Al-Tawaha ARMS (2017) Population density of marine macrobenthos: A tool for monitoring pollution-induced disturbance along Uran coast, Navi Mumbai. Adv Environ Biol 11:32-51.

75. Pearson TH, Rosenberg R (1978) Macrobenthic succession in relation to organic enrichment and pollution of the marine environment. Oceanogr Mar Biol Annu Rev 16:229-311.

76. Pillay D, Perissinotto R (2008) The benthic macrofauna of the St. Lucia estuary during the 2005 drought year. Estuar Coast Shelf Sci 77:35-46.

77. Rabindranath P (1972) Marine Gammaridea (Crustacea: Amphipoda) from the Indian region. Family Ampithoidae. Mar Biol 14:161-178.

78. Rajaneesh K, Mitbavkar S, Anil AC, Sawant SS (2015) Synechococcus as an indicator of trophic status in the Cochin backwaters, west coast of India. Ecol Ind 55, 118-130.

79. Rakocinski CF, Brown SS, Gaston GR, Heard RW, Walker WW, Summers JK (1997) Macrobenthic responses to natural and contaminant-related gradients in northern Gulf of Mexico estuaries. Ecol Appl 7:1278- 98.

80. Ramteke DS, Deshbhratar PB (2014) In: Ramteke DS, Deshbhratar PB (eds) Environmental Impact Assessment Studies for Development of Sea Port at Tadadi. Karwar: Karnataka CSIR-NEERI, pp 104.

81. Revsbech NP, Jørgensen BB (1986) Microelectrodes: their use in microbial ecology. Adv Microb Ecol 9:293-352.

82. Rhoads DC (1974) Organism-sediment relations on the muddy sea floor. Oceanogr Mar Biol Annu Rev 12:263-300.

83. Rilov G, Crooks JA (2009) Marine Bioinvason: Conservation hazards and vehicles for ecological understanding. In: Rilov G, Crooks JA (eds) Biological Invasions in marine Ecosystems: Ecological, Management, and Geographical Perspectives. Springer- Verlag Berlin Heidelberg, Ecological Studies 204, pp 3-11.

84. Rivero SM, Elías R, Vallariona EA (2005) First survey of macroinfauna in the Mar del Plata Harbour (Argentina), and the use of polychaetes as pollution indicators. Rev Biol Mar Oceanogr 40:101-108.

85. Rosenberg R (1995) Benthic marine fauna structured by hydrodynamic processes and food availability. Neth J Sea Res 34:303-31.

86. Rouse GW, Pleijel F (2001) Polychaetes (Oxford Univ. Press, 2001)

87. Sanders HL (1960) Benthic studies in Buzzards Bay, III. The structure of the soft bottom community. Limnol Oceanogr 5:138-153.

88. Sanders HL, Goudsmit EL, Hampson GE (1962) Animal-sediment relationship. Limnol Oceanogr 3:245-258.

89. Santos MFLdos, Pires-Vanin AMS (2004) Structure and dynamics of the macrobenthic communities of Ubatuba Bay, Southeastern Brazilian coast. Braz J Oceanogr 52:59-73.

90. Sarker MdJ,Tanmay MH, Rahman F, Patwary Md SA, Rima NN (2016) Macrobenthic Community Structure as A Bio-Indicator for the Assessment of Coastal Water Pollution In Greater Noakhali-Bangladesh. J Coast Zone Manag 19:2.

91. Sawant SS, Prabhudessai L, Venkat K (2007) Eutrophication status of marine environment of Mumbai and Jawaharlal Nehru ports. Environ Monit Assess 127:283-291.

92. Shephard FP (1954) Nomenclature based on sand-silt-clay ratios. J Sed Res 24(3):151-158.

93. Sivadas SK, Ingole BS, Fernandes CEG (2013) Environmental gradient favours functionally diverse macrobenthic community in a placer rich tropical bay. Sci World J 2013:12 Article ID 750580.

94. Sivadas S, Ingole B, Nanajkar M (2010) Benthic polychaetes as good indicators of anthropogenic impact. Ind J Mar Sci 39:201-12.

95. Snelgrove PVR (1998) The biodiversity of macrofaunal organisms in marine sediments. Int J Biodivers Conserv 7:1123-1132.

96. Snelgrove PVR, Butman CA (1994) Animal-sediment relationships revisited: cause versus effect. Oceanogr Mar Biol Annu Rev 32:111-177.

97. Souza FM, Gilbert ER, Camargo MG, Pieper WW (2013) The spatial distribution of the subtidal benthic macrofauna and its relationship with environmental factors using geostatistical tools: a case study in Trapandé Bay, southern Brazil. Zoologia 30:55- 65.

98. Sridhar PS (2015) A study of marine biodiversity:macrobenthos in Arabian gulf. IJMET 10:55-59.

99. Stewart PL, Kendrick PA, Robinson TL, Lee K (2002) Softbottom benthonic communities in Sydney Harbour, Nova Scotia: 1999 survey. Distribution, relation to contamination, and comparison to previous studies. Canadian Technical Report of Fish Aquat Sci 2424:92.

100. Sturdivant SK (2011) The effects of hypoxia on macrobenthic production and function in the lower Rappahannock river, Chesapeake Bay, USA. PhD dissertation, Virginia Institute of Marine Science, College of William \& Mary, Gloucester Point, Virginia.

101. Thilagavathi B, Varadharajan D, Babu A, Mano-haran J, Vijayalakshmi S, Balasubramanian T (2013) Distribution and diversity of macrobenthos in different mangrove ecosystems of Tamil Nadu Coast, India. J Aquacul Res Dev 4(6):1000199.

102. ter Braak CJF (1986) Canonical Correspondence Analysis: A New Eigenvector Technique for Multivariate Direct Gradient Analysis. J Ecol 67(5):11671179.

103. ter Braak CJF, Smilauer $P$ (2002) Canoco reference manual and CanoDraw for Windows user's guide: software for canonical community ordination (Version 4.5). Micro computer Power, Ithaca, New York, USA.

104. Tong R, Purser A, Guinan J, Unnithan V (2013) Modeling thehabitat suitability of deep-water gorgonian corals basedon terrain variables. Ecol Inform 13:123-132.

105. Wakeel-el SK, Riley JP (1956) Determination of organic carbon in marine muds. J Cons Prem Int Explor Me 22: 180-183. 
106. Walker TD, Valentine JW (1984) Equilibrium models of evolutionary species diversity and the number of empty niches. American Nature 124:887-899.

107. Wall CC, Peterson BJ, Gobler CJ (2008) Facilitation of seagrass Zostera marinaproductivity by suspension-feeding bivalves. Mar Ecol Progr Ser 357:165174.

108. Wang Y, Liu JJ, Liu W, Feng Q, Li BL, Lu H, Wang S (2021). Spatial variation in macrobenthic assemblages and their relationship with environmental factors in the upstream and midstream regions of the Heihe River Basin, China. Environ Monit Assess 193(2):1-22.

109. Weisberg SB, Ranasighe JA, Schaffner LC, Diaz RJ, Dauer DM (1997) An estuarine index of biological integrity (B-IBI) for Chesapeake Bay. Estuaries 20:149.

110. Weliange WS, Amarasinghe US, Vijverberg J, Leichtfried M, Füreder L (2017) A comparative analysis on the effects of river discharge on trophic interactions in two tropical streams. Int Rev Hydrobiol 102:3-14.

111. Wooding RA, Milley EFB, Marshall JK (1973) Drag due to regular arrays of roughness elements of varying geometry Boundary-Layer. Meteorol 5:285-308.

112. Woodward G, Hildrew AG (2002) Body-size determinants of niche overlap and intraguild predation within a complex food web. J Anim Ecol 71:10631074.

113. Zhang Y, Liu YJ, Zhang Y, Xu BQ, Lv ZB (2012) Ecological Characteristics of Benthic Polychaete Community and Its Response to Environmental Change in Laizhou Bay, Shandong Province of East China. Chin J Ecol 31(15):781-786.

\section{Tables}

Table I: Seasonal variation in temperature, salinity, dissolved oxygen, and chlorophyll-a in surface (S), near-bottom (B) seawater, and sediment (Sed.) at different sampling stations. PM I - Post monsoon I; PreM - Pre monsoon; MON - Monsoon; and PM II- Post monsoon II.

\begin{tabular}{|c|c|c|c|c|c|c|c|c|c|c|c|c|c|c|c|c|c|c|c|}
\hline \multirow[b]{3}{*}{$\begin{array}{l}\text { St. } \\
\text { no. }\end{array}$} & \multicolumn{8}{|c|}{ Temperature $\left({ }^{\circ} \mathrm{C}\right)$} & \multicolumn{8}{|c|}{ Salinity } & \multicolumn{3}{|c|}{ Dissolved oxyger } \\
\hline & \multicolumn{2}{|l|}{ PM I } & \multicolumn{2}{|l|}{ PreM } & \multicolumn{2}{|l|}{ MON } & \multicolumn{2}{|l|}{ PM II } & \multicolumn{2}{|l|}{ PM I } & \multicolumn{2}{|l|}{ PreM } & \multicolumn{2}{|l|}{ MON } & \multicolumn{2}{|l|}{ PM II } & \multicolumn{2}{|c|}{ PM I } & \multirow{2}{*}{$\frac{\text { Pre }}{\text { S }}$} \\
\hline & $S$ & B & S & B & $S$ & B & S & B & S & $\mathrm{B}$ & S & B & S & B & $S$ & B & $S$ & B & \\
\hline 1 & 29.5 & 29.6 & 28.9 & 28.1 & 26.6 & 24.9 & 29.0 & 29.1 & 35.9 & 36.0 & 35.8 & 36.4 & 34.0 & 34.7 & 34.7 & 34.8 & 4.6 & 4.3 & 4.3 \\
\hline 2 & 29.6 & 29.6 & 29.3 & 28.1 & 26.2 & 25.1 & 29.2 & 29.1 & 36.0 & 36.0 & 35.7 & 36.4 & 34.1 & 34.3 & 34.7 & 34.7 & 4.5 & 2.7 & 2.6 \\
\hline 3 & 29.7 & 29.6 & 29.5 & 28.3 & 26.3 & 24.8 & 29.3 & 29.2 & 35.8 & 36.0 & 35.6 & 36.0 & 34.8 & 34.9 & 34.7 & 34.3 & 4.3 & 3.8 & 4.2 \\
\hline 4 & 29.7 & 29.6 & 29.5 & 28.3 & 26.1 & 25.0 & 29.2 & 29.2 & 35.9 & 36.0 & 36.5 & 36.5 & 33.9 & 34.7 & 34.7 & 34.7 & 4.1 & 3.9 & 4.7 \\
\hline 5 & 29.6 & 29.6 & 29.6 & 28.4 & 26.5 & 25.0 & 29.2 & 29.2 & 35.9 & 35.9 & 36.4 & 35.7 & 34.1 & 34.4 & 34.7 & 34.7 & 3.5 & 3.5 & 3.3 \\
\hline 6 & 29.7 & 29.6 & 29.3 & 28.4 & 26.9 & 25.0 & 29.3 & 29.2 & 35.9 & 35.9 & 35.8 & 35.9 & 34.8 & 34.9 & 34.9 & 34.9 & 3.2 & 2.5 & 2.7 \\
\hline 7 & 29.9 & 29.6 & 29.1 & 28.0 & 25.4 & 25.0 & 29.3 & 29.2 & 35.8 & 35.8 & 35.6 & 35.9 & 34.8 & 34.0 & 34.8 & 34.8 & 4.1 & 3.8 & 4.6 \\
\hline 8 & 29.7 & 29.5 & 29.8 & 27.8 & 25.4 & 25.1 & 29.4 & 29.3 & 35.8 & 36.0 & 35.5 & 35.8 & 34.2 & 34.8 & 34.7 & 34.8 & 4.1 & 2.4 & 6.0 \\
\hline 9 & 29.7 & 29.5 & 29.0 & 28.0 & 25.6 & 25.0 & 29.1 & 29.0 & 35.8 & 35.5 & 35.7 & 36.2 & 34.6 & 34.7 & 34.8 & 34.8 & 4.6 & 2.1 & 4.6 \\
\hline 10 & 29.2 & 29.2 & 29.3 & 27.8 & 25.4 & 25.0 & 29.0 & 29.0 & 36.0 & 36.0 & 35.6 & 35.8 & 34.9 & 34.8 & 34.9 & 34.9 & 2.3 & 2.6 & 7.0 \\
\hline 11 & 29.4 & 29.3 & 29.4 & 27.8 & 25.6 & 24.9 & 29.4 & 29.1 & 36.1 & 36.0 & 35.7 & 36.3 & 34.4 & 34.9 & 34.8 & 34.8 & 2.1 & 1.2 & 3.0 \\
\hline 12 & 29.5 & 29.3 & 29.5 & 27.8 & 25.5 & 24.9 & 29.4 & 29.2 & 36.1 & 36.0 & 35.7 & 35.9 & 33.8 & 34.8 & 34.7 & 34.8 & 2.4 & 2.0 & 6.9 \\
\hline 13 & 29.5 & 29.3 & 30.0 & 28.0 & 25.8 & 25.0 & 29.4 & 29.2 & 36.1 & 36.0 & 35.7 & 35.8 & 34.2 & 34.8 & 34.8 & 34.9 & 2.1 & 2.0 & 7.7 \\
\hline 14 & 29.5 & 29.2 & 29.9 & 27.9 & 26.2 & 25.2 & 29.4 & 29.1 & 36.0 & 35.0 & 35.7 & 36.0 & 34.5 & 34.7 & 34.8 & 34.8 & 2.9 & 2.7 & 7.8 \\
\hline 15 & 29.7 & 29.5 & 29.9 & 27.6 & 26.6 & 25.1 & 29.0 & 29.0 & 35.8 & 36.0 & 35.7 & 35.7 & 34.4 & 34.8 & 34.8 & 34.8 & 3.4 & 0.9 & 6.6 \\
\hline 16 & 29.6 & 29.5 & 29.7 & 27.8 & 26.6 & 25.3 & 29.0 & 28.9 & 35.8 & 35.9 & 35.2 & 35.9 & 34.4 & 34.9 & 34.4 & 34.5 & 1.7 & 0.6 & 7.6 \\
\hline 17 & 29.6 & 29.5 & 29.6 & 27.6 & 26.3 & 25.3 & - & - & 35.8 & 35.8 & 34.5 & 34.8 & 34.8 & 34.9 & 34.4 & 34.6 & 5.0 & 2.3 & 4.2 \\
\hline 18 & 29.6 & 29.5 & 29.7 & 28.3 & 26.6 & 25.4 & 29.2 & 28.8 & 35.8 & 36.1 & 35.7 & 36.7 & 34.3 & 34.9 & 34.8 & 34.7 & 4.8 & 3.1 & 5.8 \\
\hline 19 & 29.8 & 29.5 & 29.3 & 27.8 & 25.8 & 25.3 & 29.6 & 28.9 & 35.7 & 36.0 & 35.7 & 35.8 & 34.2 & 35.0 & 34.8 & 34.9 & - & - & 4.2 \\
\hline $\begin{array}{l}\text { AVG } \\
\pm \\
\text { STD }\end{array}$ & $\begin{array}{l}29.6 \\
\pm 0.2\end{array}$ & $\begin{array}{l}29.5 \\
\pm 0.1\end{array}$ & $\begin{array}{l}29.5 \\
\pm 0.3\end{array}$ & $\begin{array}{l}28 \\
\pm \\
0.3\end{array}$ & $\begin{array}{l}26.1 \\
\pm 0.5\end{array}$ & $\begin{array}{l}25.1 \\
\pm 0.2\end{array}$ & $\begin{array}{l}29.2 \\
\pm 0.2\end{array}$ & $\begin{array}{l}29.1 \\
\pm 0.1\end{array}$ & $\begin{array}{l}35.9 \\
\pm 0.1\end{array}$ & $\begin{array}{l}35.9 \\
\pm 0.3\end{array}$ & $\begin{array}{l}35.7 \\
\pm 0.4\end{array}$ & $\begin{array}{l}36 \\
\pm \\
0.4\end{array}$ & $\begin{array}{l}34.4 \\
\pm 0.3\end{array}$ & $\begin{array}{l}34.7 \\
\pm 0.2\end{array}$ & $\begin{array}{l}34.7 \\
\pm 0.1\end{array}$ & $\begin{array}{l}34.7 \\
\pm 0.2\end{array}$ & $\begin{array}{l}3.5 \\
\pm \\
1.1\end{array}$ & $\begin{array}{l}2.6 \\
\pm 1\end{array}$ & $\begin{array}{l}5.1 \\
\pm \\
1.7\end{array}$ \\
\hline
\end{tabular}

Table II: Results of the Two-way ANOVA of seasonal variation in the abundance and biomass of macrobenthic organisms, and sediment parameters at different stations. 


\begin{tabular}{|c|c|c|c|c|c|c|c|}
\hline Source & $\begin{array}{l}\text { Dependent } \\
\text { Variable }\end{array}$ & Type III Sum of Squares & df & $\begin{array}{l}\text { Mean } \\
\text { Square }\end{array}$ & $\mathbf{F}$ & Sig. & $\begin{array}{l}\text { Partial Eta } \\
\text { Squared }\end{array}$ \\
\hline \multirow[t]{7}{*}{ Stations } & Abundance & 24.292 & 16 & 1.518 & 408.330 & .001 & 0.992 \\
\hline & Biomass & 19.296 & 16 & 1.206 & 521.332 & .001 & 0.994 \\
\hline & Chlorophyll-a & 2.391 & 16 & 0.149 & $1.482 \mathrm{E} 3$ & .001 & 0.998 \\
\hline & Organic carbon & 0.363 & 16 & 0.023 & 11.388 & .001 & 0.785 \\
\hline & Sand & 1.043 & 16 & 0.065 & 15.314 & .001 & 0.831 \\
\hline & Silt & 1.850 & 16 & 0.116 & 32.445 & .001 & 0.912 \\
\hline & Clay & 5.448 & 16 & 0.341 & 140.456 & .001 & 0.978 \\
\hline \multirow[t]{7}{*}{ Seasons } & Abundance & 11.127 & 3 & 3.709 & 997.490 & .001 & 0.984 \\
\hline & Biomass & 11.840 & 3 & 3.947 & $1.706 \mathrm{E} 3$ & .001 & 0.990 \\
\hline & Chlorophyll-a & 0.462 & 3 & 0.154 & $1.528 \mathrm{E} 3$ & .001 & 0.989 \\
\hline & Organic carbon & 0.609 & 3 & 0.203 & 101.883 & .001 & 0.859 \\
\hline & Sand & 0.604 & 3 & 0.201 & 47.310 & .001 & 0.739 \\
\hline & Silt & 0.184 & 3 & 0.061 & 17.182 & .001 & 0.508 \\
\hline & Clay & 0.307 & 3 & 0.102 & 42.170 & .001 & 0.717 \\
\hline
\end{tabular}

Table IIIA: Number of species $(S)$, Number of specimens $(M)$, Margalef species richness $(d)$, Pielou's evenness $(J)$, Shannon index $(H)$, of microbenthic species during (A) Post-monsoon I (B) Pre-monsoon (C) Monsoon and (D) Post- monsoon II in New Mangalore Port.

(A) PM I

\begin{tabular}{|c|c|c|c|c|c|}
\hline Stations & $S$ & $\mathbf{N}$ & d & $\mathrm{J}^{\prime}$ & $H^{\prime}(\log 2)$ \\
\hline 1 & 0 & 0 & - & - & 0 \\
\hline 2 & 1 & 3 & 0 & - & 0 \\
\hline 3 & 2 & 7 & 0.517 & 1 & 1 \\
\hline 4 & 3 & 12 & 0.8031 & 0.9984 & 1.582 \\
\hline 5 & 2 & 6 & 0.5454 & 0.9919 & 0.9919 \\
\hline 6 & 4 & 13 & 1.156 & 0.9873 & 1.975 \\
\hline 7 & 0 & 0 & - & - & 0 \\
\hline 8 & 1 & 3 & 0 & - & 0 \\
\hline 9 & 1 & 3 & 0 & - & 0 \\
\hline 10 & 0 & 0 & - & - & 0 \\
\hline 11 & 0 & 0 & - & - & 0 \\
\hline 12 & 0 & 0 & - & - & 0 \\
\hline 13 & 1 & 3 & 0 & - & 0 \\
\hline 14 & 1 & 4 & 0 & - & 0 \\
\hline 15 & 3 & 11 & 0.8407 & 0.9821 & 1.557 \\
\hline 16 & 0 & 0 & - & - & 0 \\
\hline 17 & 3 & 11 & 0.8316 & 0.9767 & 1.548 \\
\hline 18 & 4 & 15 & 1.104 & 0.9873 & 1.975 \\
\hline 19 & 0 & 0 & - & - & 0 \\
\hline
\end{tabular}

(B) PreM 


\begin{tabular}{|c|c|c|c|c|c|}
\hline Stations & $S$ & $N$ & $d$ & $J^{\prime}$ & $H^{\prime}(\log 2)$ \\
\hline 1 & 6 & 18 & 1.719 & 0.9909 & 2.561 \\
\hline 2 & 4 & 12 & 1.198 & 0.9923 & 1.985 \\
\hline 3 & 2 & 9 & 0.4589 & 0.9657 & 0.9657 \\
\hline 4 & 5 & 18 & 1.396 & 0.984 & 2.285 \\
\hline 5 & 7 & 26 & 1.851 & 0.9873 & 2.772 \\
\hline 6 & 9 & 33 & 2.279 & 0.9878 & 3.131 \\
\hline 7 & 1 & 3 & 0 & - & 0 \\
\hline 8 & 7 & 24 & 1.876 & 0.9912 & 2.783 \\
\hline 9 & 4 & 12 & 1.213 & 0.9967 & 1.993 \\
\hline 10 & 0 & 0 & - & - & 0 \\
\hline 11 & 3 & 8 & 0.9402 & 1 & 1.585 \\
\hline 12 & 3 & 9 & 0.9078 & 0.9952 & 1.577 \\
\hline 13 & 3 & 9 & 0.8905 & 0.989 & 1.567 \\
\hline 14 & 4 & 12 & 1.213 & 0.9967 & 1.993 \\
\hline 15 & 1 & 3 & 0 & - & 0 \\
\hline 16 & 0 & 0 & - & - & 0 \\
\hline 17 & 2 & 6 & 0.5454 & 0.9919 & 0.9919 \\
\hline 18 & 24 & 95 & 5.051 & 0.9781 & 4.485 \\
\hline 19 & 0 & 0 & - & - & 0 \\
\hline
\end{tabular}

\section{(C) MON}

\begin{tabular}{|c|c|c|c|c|c|}
\hline Stations & $S$ & $\mathbf{N}$ & d & $J^{\prime}$ & $H^{\prime}(\log 2)$ \\
\hline 1 & 0 & 0 & - & - & 0 \\
\hline 2 & 2 & 6 & 0.5454 & 0.9919 & 0.9919 \\
\hline 3 & 2 & 7 & 0.5082 & 0.9654 & 0.9654 \\
\hline 4 & 1 & 5 & 0 & - & 0 \\
\hline 5 & 1 & 3 & 0 & - & 0 \\
\hline 6 & 2 & 11 & 0.4185 & 0.9987 & 0.9987 \\
\hline 7 & 0 & 0 & - & - & 0 \\
\hline 8 & 1 & 3 & 0 & - & 0 \\
\hline 9 & 0 & 0 & - & - & 0 \\
\hline 10 & 0 & 0 & - & - & 0 \\
\hline 11 & 0 & 0 & - & - & 0 \\
\hline 12 & 0 & 0 & - & - & 0 \\
\hline 13 & 1 & 5 & 0 & - & 0 \\
\hline 14 & 5 & 18 & 1.385 & 0.9891 & 2.297 \\
\hline 15 & 1 & 4 & 0 & - & 0 \\
\hline 16 & 0 & 0 & - & - & 0 \\
\hline 17 & 2 & 6 & 0.5808 & 1 & 1 \\
\hline 18 & 16 & 62 & 3.631 & 0.9818 & 3.927 \\
\hline 19 & 1 & 3 & 0 & - & 0 \\
\hline
\end{tabular}

(D) PM II 


\begin{tabular}{|c|c|c|c|c|c|}
\hline Stations & $s$ & $N$ & $d$ & $J^{\prime}$ & $H^{\prime}(\log 2)$ \\
\hline 1 & 5 & 19 & 1.369 & 0.9824 & 2.311 \\
\hline 2 & 3 & 10 & 0.8644 & 0.9922 & 1.581 \\
\hline 3 & 0 & 0 & - & - & 0 \\
\hline 4 & 14 & 60 & 3.17 & 0.9751 & 3.786 \\
\hline 5 & 5 & 16 & 1.452 & 0.9941 & 2.318 \\
\hline 6 & 3 & 16 & 0.721 & 0.9757 & 1.577 \\
\hline 7 & 0 & 0 & - & - & 0 \\
\hline 8 & 3 & 9 & 0.9078 & 0.9952 & 1.583 \\
\hline 9 & 8 & 30 & 2.063 & 0.9742 & 2.983 \\
\hline 10 & 12 & 42 & 2.941 & 0.9888 & 3.575 \\
\hline 11 & 6 & 18 & 1.735 & 0.9954 & 2.582 \\
\hline 12 & 0 & 0 & - & - & 0 \\
\hline 13 & 0 & 0 & - & - & 0 \\
\hline 14 & 5 & 16 & 1.435 & 0.9787 & 2.31 \\
\hline 15 & 0 & 0 & - & - & 0 \\
\hline 16 & 0 & 0 & - & - & 0 \\
\hline 17 & 10 & 38 & 2.475 & 0.98 & 3.307 \\
\hline 18 & 31 & 121 & 6.253 & 0.9843 & 4.937 \\
\hline 19 & 3 & 11 & 0.8467 & 0.9852 & 1.579 \\
\hline
\end{tabular}

Table IIIB: Number of species $(S)$, Number of specimens $(N)$, Margalef species richness $(d)$, Pielou's evenness $(J)$, Shannon index $(H)$, of macrobenthic species during Post-monsoon I, Pre-monsoon, Monsoon, and Post-monsoon II with respect different areas (LCA, OFW and HCA) within the port New Mangalore Port. 


\begin{tabular}{|c|c|c|c|c|c|c|c|c|c|c|c|c|c|c|c|c|c|c|c|}
\hline \multicolumn{6}{|c|}{ Post-monsoon I } & \multicolumn{5}{|c|}{ Premonsoon } & \multicolumn{5}{|c|}{ Monsoon } & \multicolumn{4}{|c|}{ Post-monsoon II } \\
\hline \multicolumn{6}{|c|}{ LCA } & \multicolumn{5}{|c|}{ LCA } & \multicolumn{5}{|c|}{ LCA } & \multicolumn{4}{|c|}{ LCA } \\
\hline St. & $S$ & $\mathrm{~N}$ & $d$ & $J^{\prime}$ & $\begin{array}{l}\mathrm{H}^{\prime} \\
(\log 2)\end{array}$ & $S$ & $\mathrm{~N}$ & $\mathrm{~d}$ & $J^{\prime}$ & $\begin{array}{l}\mathrm{H}^{\prime} \\
(\log 2)\end{array}$ & $S$ & $\mathrm{~N}$ & $d$ & $J^{\prime}$ & $\begin{array}{l}\mathrm{H}^{\prime} \\
(\log 2)\end{array}$ & $S$ & $\mathrm{~N}$ & $d$ & $J^{\prime}$ \\
\hline 1 & 0 & 0 & - & - & 0 & 6 & 18 & 1.719 & 0.991 & 2.561 & 0 & 0 & - & - & 0 & 5 & 19 & 1.369 & 0.982 \\
\hline 2 & 1 & 3 & 0 & 0 & 0 & 4 & 12 & 1.198 & 0.992 & 1.985 & 2 & 6 & 0.545 & 0.992 & 0.9919 & 3 & 10 & 0.864 & 0.992 \\
\hline 3 & 2 & 7 & 0.517 & 1 & 1 & 2 & 9 & 0.459 & 0.966 & 0.9657 & 2 & 7 & 0.508 & 0.965 & 0.9654 & 0 & 0 & 0 & 0 \\
\hline 4 & 3 & 12 & 0.803 & 0.998 & 1.582 & 5 & 18 & 1.396 & 0.984 & 2.285 & 1 & 5 & 0 & 0 & 0 & 14 & 60 & 3.17 & 0.975 \\
\hline 5 & 2 & 6 & 0.545 & 0.992 & 0.9919 & 7 & 26 & 1.851 & 0.987 & 2.772 & 1 & 3 & 0 & 0 & 0 & 5 & 16 & 1.452 & 0.994 \\
\hline 6 & 4 & 13 & 1.156 & 0.987 & 1.975 & 9 & 33 & 2.279 & 0.988 & 3.131 & 2 & 11 & 0.418 & 0.999 & 0.9987 & 3 & 16 & 0.721 & 0.976 \\
\hline 7 & 0 & 0 & - & - & 0 & 1 & 3 & 0 & 0 & 0 & 0 & 0 & 0 & - & 0 & 0 & 0 & 0 & - \\
\hline 8 & 1 & 3 & 0 & 0 & 0 & 7 & 24 & 1.876 & 0.991 & 2.783 & 1 & 3 & 0 & 0 & 0 & 3 & 9 & 0.908 & 0.995 \\
\hline \multicolumn{6}{|c|}{ OFW } & \multicolumn{5}{|c|}{ OFW } & \multicolumn{5}{|c|}{ OFW } & \multicolumn{4}{|c|}{ OFW } \\
\hline 10 & 0 & 0 & - & - & 0 & 0 & 0 & - & - & 0 & 0 & 0 & - & - & 0 & 12 & 42 & 2.941 & 0.988 \\
\hline 11 & 0 & 0 & - & - & 0 & 3 & 8 & 0.940 & 1 & 1.585 & 0 & 0 & - & - & 0 & 6 & 18 & 1.735 & 0.995 \\
\hline 12 & 0 & 0 & - & - & 0 & 3 & 9 & 0.908 & 0.995 & 1.577 & 0 & 0 & - & - & 0 & 0 & 0 & 0 & - \\
\hline 13 & 1 & 3 & 0 & 0 & 0 & 3 & 9 & 0.890 & 0.989 & 1.567 & 1 & 5 & 0 & 0 & 0 & 0 & 0 & 0 & - \\
\hline 14 & 1 & 4 & 0 & 0 & 0 & 4 & 12 & 1.213 & 0.997 & 1.993 & 5 & 18 & 1.38 & 0.989 & 2.297 & 5 & 16 & 1.435 & 0.979 \\
\hline \multicolumn{6}{|c|}{$\mathrm{HCA}$} & \multicolumn{5}{|c|}{$\mathrm{HCA}$} & \multicolumn{5}{|c|}{$\mathrm{HCA}$} & \multicolumn{4}{|c|}{$\mathrm{HCA}$} \\
\hline 9 & 1 & 3 & 0 & 0 & 0 & 4 & 12 & 1.213 & 0.997 & 1.993 & 1 & 5 & 0 & - & 0 & 8 & 30 & 2.063 & 0.974 \\
\hline 15 & 3 & 11 & 0.841 & 0.982 & 1.557 & 1 & 3 & 0 & 0 & 0 & 1 & 4 & 0 & 0 & 0 & 0 & 0 & 0 & - \\
\hline 16 & 0 & 0 & - & - & 0 & 0 & 0 & 0 & - & 0 & 0 & 0 & 0 & - & 0 & 0 & 0 & 0 & - \\
\hline 17 & 3 & 11 & 0.832 & 0.977 & 1.548 & 2 & 6 & 0.545 & 0.992 & 0.9919 & 2 & 6 & 0.581 & 1 & 1 & 10 & 38 & 2.475 & 0.98 \\
\hline 18 & 4 & 15 & 1.104 & 0.987 & 1.975 & 23 & 90 & 4.89 & 0.977 & 4.42 & 16 & 62 & 3.631 & 0.9818 & 3.927 & 31 & 121 & 6.253 & 0.984 \\
\hline 19 & 0 & 0 & - & - & 0 & 0 & 0 & - & - & 0 & 1 & 3 & 0 & 0 & 0 & 3 & 11 & 0.847 & 0.985 \\
\hline
\end{tabular}

\section{Figures}




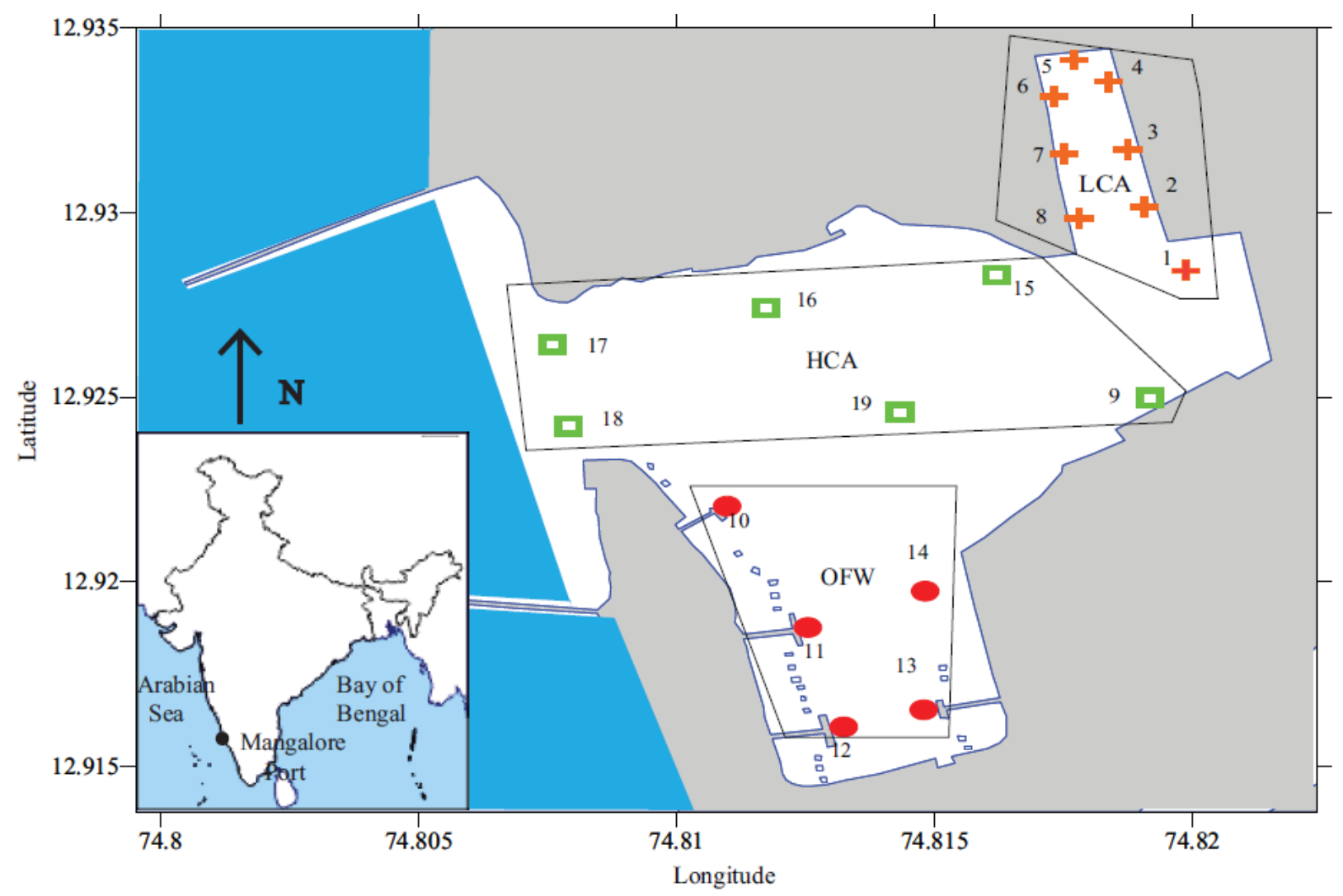

\section{Figure 1}

Map of the study area and sampling stations at New Mangalore Port. Low Circulation Area (LCA) stations - st-1 (Berth No.1), st-2 (Berth No.2), st-3 (Berth No.3), st-4 (Berth No.4), st-5 (Northern Return), st-6 (Berth No.5), st-7 (Berth No.6), st-8 (Berth No.7); Oil and Fertilizer Warf (OFW) stations - st-10 (Berth No.9), st-11 (Berth No.10), st-12 (Berth No.11), st-13 (Berth No.12), st-14 (Berth No.13); High Circulation Area (HCA) stations - st-9 (Berth No.8), st-15 (Berth No.14), st-16 (Berth No.15), st-17 (Channel Marker Buoy-1), st-18 (Channel Marker Buoy-2), st-19 (Turning Circle). 


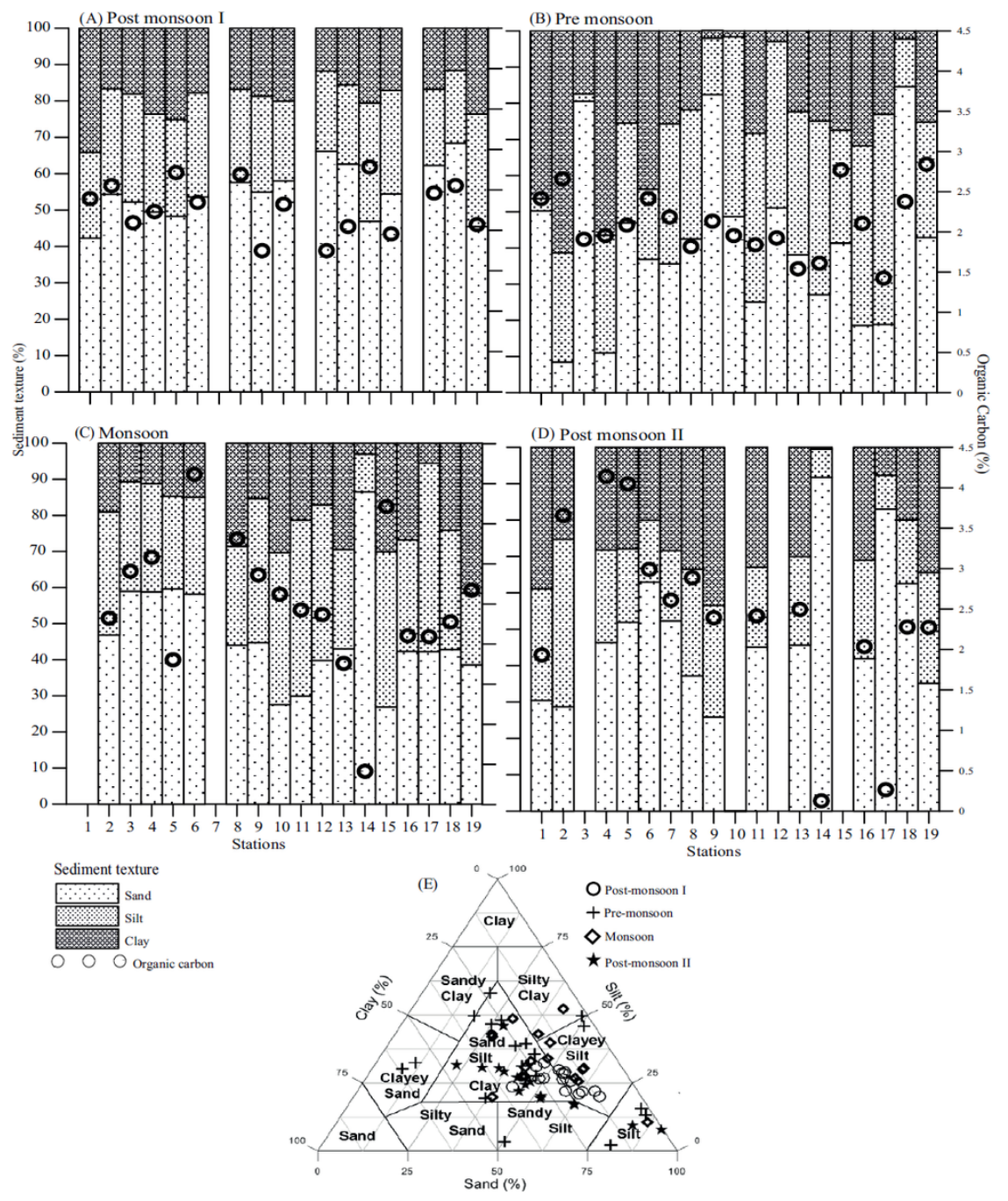

\section{Figure 2}

Seasonal variation in the sediment characteristics (percentage) in New Mangalore port (A) post-monsoon I (B) pre-monsoon (C) monsoon (D) post-monsoon II (E) ternary triangle. 
(A) Post monsoon I

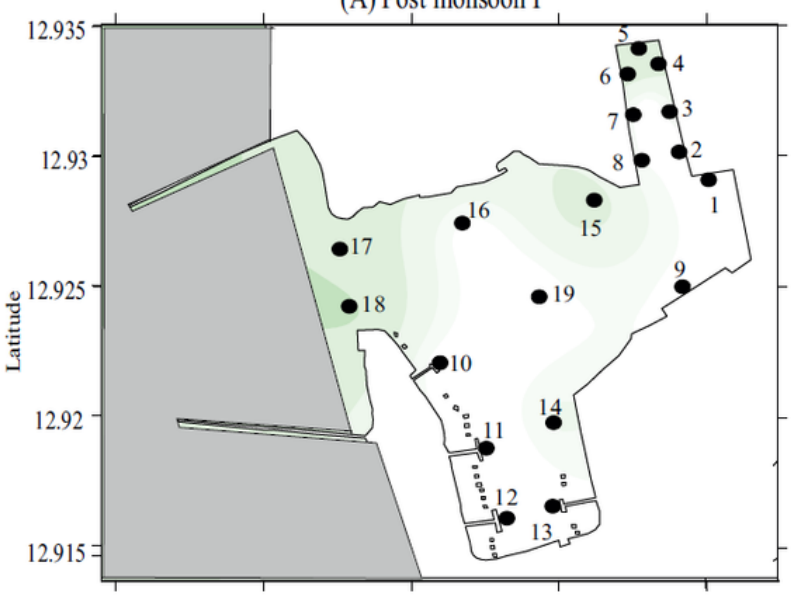

(C) Monsoon

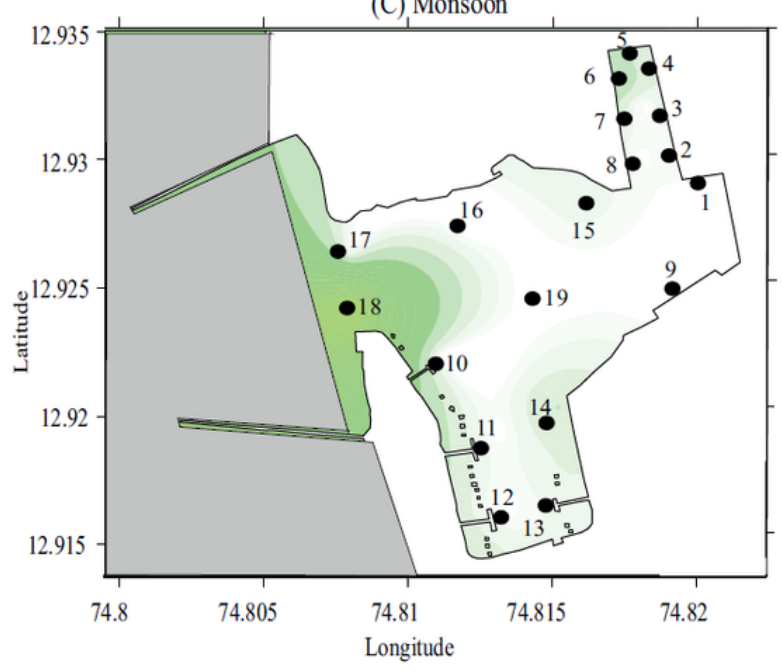

(B) Pre monsoon

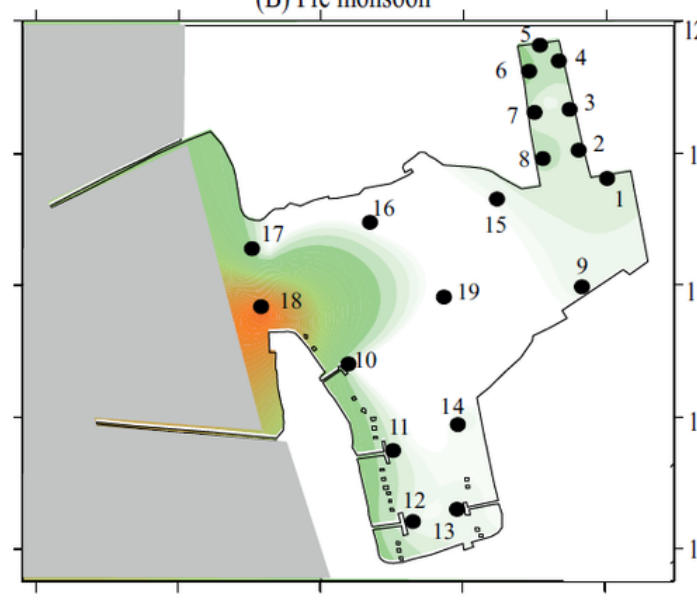

12.935

$-12.93$

$-12.915$

(D) Post monsoon II

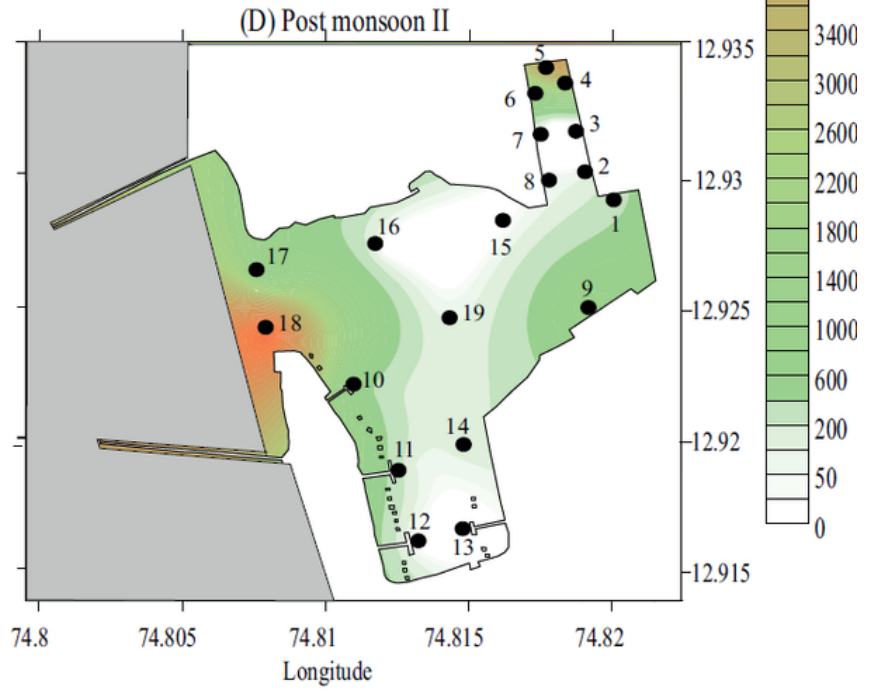

Figure 3

Seasonal variation in the abundance (no. m-2) of macrobenthic taxa at different stations in New Mangalore port (A) Post monsoon I (B) Pre monsoon (C) Monsoon and (D) Post monsoon II. 


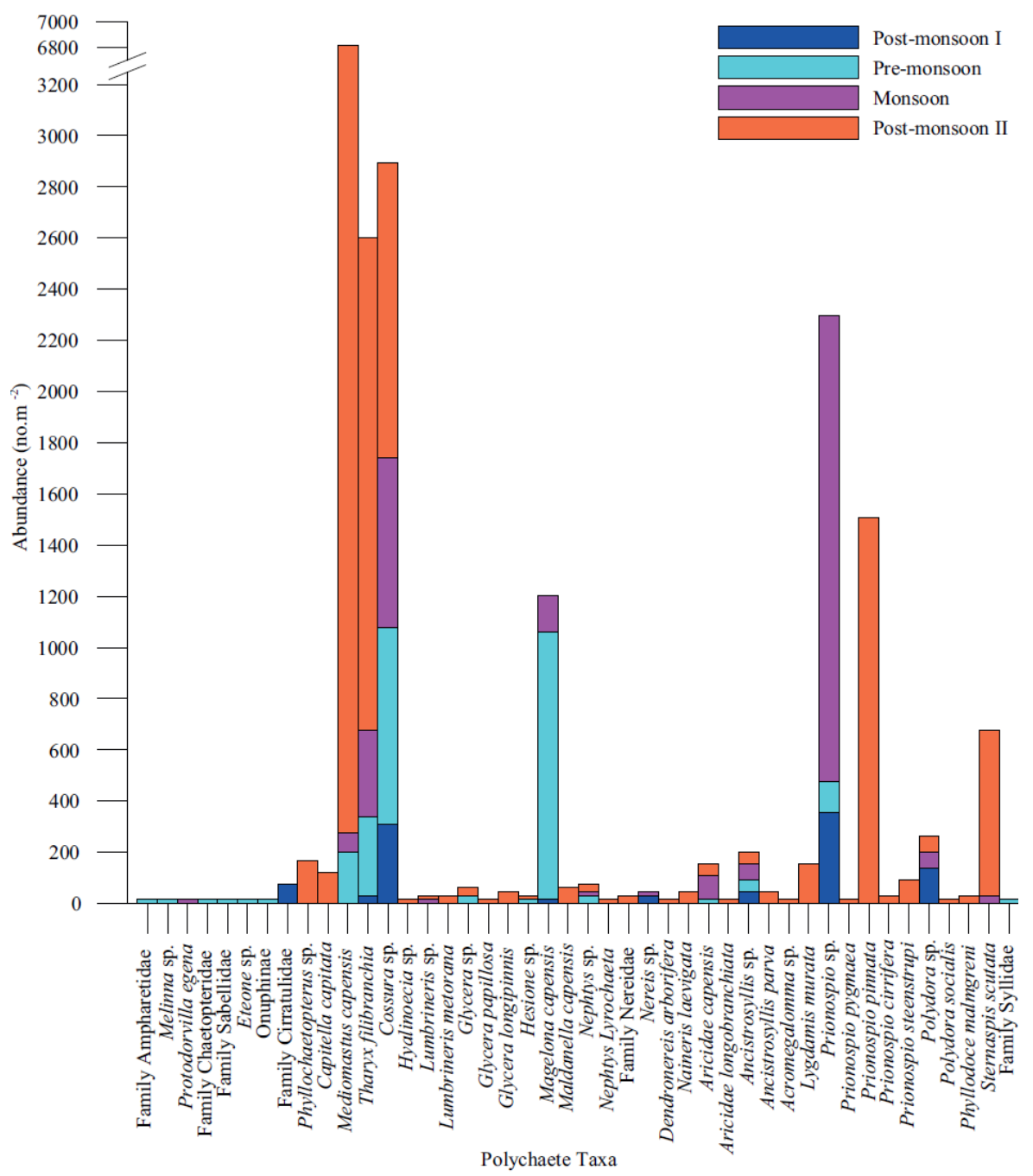

Figure 4

Seasonal variation in the abundance (no. m-2) of polychaete taxa in New Mangalore port. 

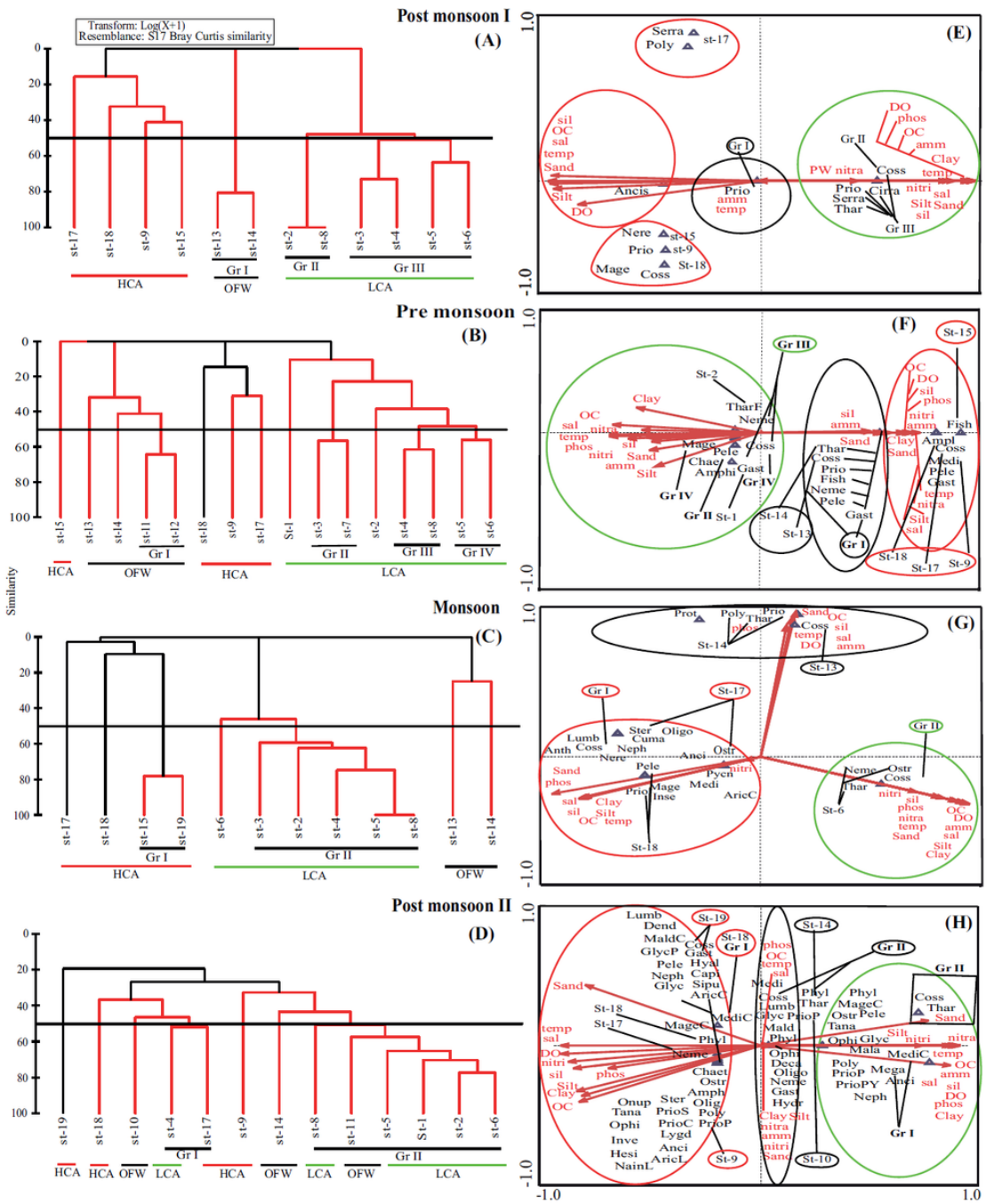

\section{Figure 5}

Analysis of cluster and SIMPROF of the stations from different areas showing relation between abundance of macrobenthos with environmental variables and sediment characteristics during different seasons (A) Post monsoon I (B) Pre monsoon (C) Monsoon (D) Post monsoon II. The tables represent the grouping of stations based on the occurrance of macrobenthic species and the environmental parameters and sediment charcateristcs influencing the macrobenthic species. The macrobenthos taxa have been abbreviated as follows: Cirratudiae: Cirr; Tharyx filibranchia: TharF; Cossura sp.: Coss; Magelona capenis: MageC; Nereis sp.: Nere; Ancistrosyllis sp.: Anci; Prionospio sp.: Prio; Polydora sp.: Poly; Serratosagitta sp.: Serra; Mediomastus capensis: Gastropods: Gast; Pelecypods: Pele; Amphipods: Amphi; Ostrocods: Ostro; Nemertea: Neme; Insecta: Inse; Phyllodocidae sp.: Phyl; Different bottom water environmental parameters, pore water nutrients are abbreviated as follows: Pore water silicate: sil; Pore water nitrate: nitra; Pore water nitrite: nitri; Pore water ammonium: amm; Pore water phosphate: phos; Bottom water temperature: temp; Bottom water salinity: sal; Bottom water dissolved oxygen: DO; Sediment OC: OC.

\section{Supplementary Files}

This is a list of supplementary files associated with this preprint. Click to download.

- SupplementaryFigure1.eps

- SupplemetaryTable1.docx 